\title{
Hydrothermal activity lowers trophic diversity in Antarctic hydrothermal sediments
}

\author{
James B. Bell ${ }^{1,2,3}$, William D. K. Reid ${ }^{4}$, David A. Pearce ${ }^{5}$, Adrian G. Glover ${ }^{2}$, Christopher J. Sweeting ${ }^{4}$, \\ Jason Newton ${ }^{6}$, and Clare Woulds ${ }^{1}$ \\ ${ }^{1}$ School of Geography \& Water at Leeds, University of Leeds, LS2 9JT, UK \\ ${ }^{2}$ Life Sciences Dept., Natural History Museum, Cromwell Rd, London SW7 5BD, UK \\ ${ }^{3}$ Centre for Environment, Fisheries and Aquaculture Science, Lowestoft NR34 0HT, UK \\ ${ }^{4}$ Marine Sciences-School of Natural and Environmental Sciences, Ridley Building, \\ Newcastle University, NE1 7RU, UK \\ ${ }^{5}$ Applied Sciences, Northumbria University, Newcastle NE1 8ST, UK \\ ${ }^{6}$ NERC Life Sciences Mass Spectrometry Facility, SUERC, East Kilbride G75 0QF, UK
}

Correspondence: Clare Woulds (c.woulds@leeds.ac.uk)

Received: 5 July 2017 - Discussion started: 1 August 2017

Revised: 25 October 2017 - Accepted: 6 November 2017 - Published: 20 December 2017

\begin{abstract}
Hydrothermal sediments are those in which hydrothermal fluid is discharged through sediments and are one of the least studied deep-sea ecosystems. We present a combination of microbial and biochemical data to assess trophodynamics between and within hydrothermal and background areas of the Bransfield Strait (1050-1647 m of depth). Microbial composition, biomass, and fatty acid signatures varied widely between and within hydrothermally active and background sites, providing evidence of diverse metabolic activity. Several species had different feeding strategies and trophic positions between hydrothermally active and inactive areas, and the stable isotope values of consumers were not consistent with feeding morphology. Niche area and the diversity of microbial fatty acids was lowest at the most hydrothermally active site, reflecting trends in species diversity. Faunal uptake of chemosynthetically produced organics was relatively limited but was detected at both hydrothermal and non-hydrothermal sites, potentially suggesting that hydrothermal activity can affect trophodynamics over a much wider area than previously thought.
\end{abstract}

\section{Introduction}

Hydrothermal sediments (also called sediment-hosted or sedimented hydrothermal vents), the product of subsurface mixing between hydrothermal fluid and ambient seawater within the sediment, are physically more similar to background deep-sea habitats than to high-temperature hard substratum vents (Bemis et al., 2012; Bernardino et al., 2012). This means that whilst they can host chemosynthetic obligate species, they can also be more easily colonised by nonspecialist fauna and potentially offer an important metabolic resource in the nutrient-limited deep sea (Levin et al., 2009; Dowell et al., 2016). Hydrothermal sediments have also been suggested to act as evolutionary bridges between hard substratum vents and methane seeps (Kiel, 2016). To utilise in situ production in hydrothermal sediments, fauna must overcome the environmental stress associated with hightemperature, acidic, and toxic conditions (Levin et al., 2013; Gollner et al., 2015). The combination of elevated toxicity and in situ organic matter (OM) production results in a different complement of ecological niches between hydrothermal and background conditions that elicits compositional changes along a productivity-toxicity gradient (Bernardino et al., 2012; Gollner et al., 2015; Bell et al., 2016b). Hydrothermal sediments offer different relative abundances of chemosynthetic and photosynthetic organic matter, depending upon the supply of surface-derived primary productiv- 
ity and levels of hydrothermal activity (Tarasov et al., 2005). In shallow environments $(<200 \mathrm{~m}$ of depth) where the production of chemosynthetic and photosynthetic organic matter sources can co-occur, consumption may still favour photosynthetic OM over chemosynthetic OM as this does not require physiological adaptations to environmental toxicity (Kharlamenko et al., 1995; Tarasov et al., 2005; Sellanes et al., 2011). The limited data available concerning trophodynamics at deep-sea hydrothermal sediments in the Arctic indicate that diet composition can vary widely between species (Sweetman et al., 2013).

Hydrothermal sediments host diverse microbial communities (Teske et al., 2002; Kallmeyer and Boetius, 2004). Microbial communities are a vital intermediate between inorganic substrates and metazoan consumers, and thus their composition and isotopic signatures are of direct relevance to metazoan food webs. The heat flux associated with hydrothermal activity provides both benefits and constraints to microbial communities (Kallmeyer and Boetius, 2004; Teske et al., 2014) and accelerates the degradation of organic matter, giving rise to a wide variety of compounds including hydrocarbons and organic acids (Martens, 1990; Whiticar and Suess, 1990; Dowell et al., 2016). Microbial aggregations are commonly visible on the sediment surface in hydrothermal sediments (Levin et al., 2009; Sweetman et al., 2013; Dowell et al., 2016), but microbial activity also occurs throughout the underlying sediment, occupying a wide range of geochemical and thermal niches (reviewed by Teske et al., 2014). Sedimented chemosynthetic ecosystems may present several sources of organic matter to consumers (Bernardino et al., 2012; Sweetman et al., 2013; Yamanaka et al., 2015) and the diverse microbial assemblages can support a variety of reaction pathways, including methane oxidation, sulfide oxidation, sulfate reduction, and nitrogen fixation (Teske et al., 2002; Dekas et al., 2009; Jaeschke et al., 2014). Phospholipid fatty acid (PLFA) analysis can be used to describe recent microbial activity and $\delta^{13} \mathrm{C}$ signatures (Boschker and Middelburg, 2002; Yamanaka and Sakata, 2004; Colaço et al., 2007). Although it can be difficult to ascribe a PLFA to a specific microbial group or process, high relative abundances of certain PLFAs can be strongly indicative of chemoautotrophy (Yamanaka and Sakata, 2004; Colaço et al., 2007) and can support an understanding of microbial ecosystem function in hydrothermal sediments (e.g. in western Pacific vents; see Yamanaka and Sakata, 2004).

Macrofaunal assemblages in Bransfield hydrothermal sediments were strongly influenced by hydrothermal activity (Bell et al., 2016b, 2017a). Bacterial mats were widespread across Hook Ridge, where variable levels of hydrothermal activity were detected (Aquilina et al., 2013). Populations of siboglinid polychaetes (Sclerolinum contortum and Siboglinum spp.) were found at Hook Ridge and non-hydrothermally active sites (Sahling et al., 2005; Georgieva et al., 2015; Bell et al., 2016b) and can har- bour chemoautotrophic endosymbionts (Schmaljohann et al., 1990; Eichinger et al., 2013; Rodrigues et al., 2013).

Stable isotope analysis (SIA) is a powerful tool to assess spatial and temporal patterns in faunal feeding behaviour and has been used to study trophodynamics and resource partitioning in other hydrothermal sediments, predominately in the Pacific (Fry et al., 1991; Levin et al., 2009; Portail et al., 2016). Stable isotopic analyses provide inferential measures of different synthesis pathways and can elucidate a wide range of autotrophic or feeding behaviours. Carbon and sulfur isotopes are used to delineate food sources and nitrogen to estimate trophic position. The signature of source isotope ratios $\left(\delta^{13} \mathrm{C}\right.$ and $\left.\delta^{34} \mathrm{~S}\right)$ is influenced by the isotopic ratio of the chemical substrate and the fractionation associated with the metabolic process involved; thus, different fixation pathways can elicit different isotopic signatures, even when derived from a single source (e.g. DIC; Fry et al., 1991). Possible $\delta^{13} \mathrm{C}$ isotopic values of sources in the Bransfield Strait include $\sim-40 \%$ ofor thermogenic methane, $\sim-27 \%$ o for suspended particulate matter, and $\sim-15 \%$ o for ice algae (Whiticar and Suess, 1990; Mincks et al., 2008; Henley et al., 2012; Young et al., 2013). As an example, Siboglinum spp. can use a range of resources, including methane or dissolved organic matter (Southward et al., 1979; Schmaljohann et al., 1990; Thornhill et al., 2008; Rodrigues et al., 2013), making SIA an ideal way to examine resource utilisation in these settings (Levin et al., 2009; Soto, 2009). We also apply the concept of an isotopic niche (Layman et al., 2007) whereby species or community trophic activity is inferred from the distribution of stable isotopic data in two- or threedimensional isotope space.

\section{Hypotheses}

We used a combination of microbial diversity data based on sequencing and compound-specific isotopic analyses and bulk isotopic data from sediment, microbial, macrofaunal, and megafaunal samples to investigate resource utilisation, niche partitioning, and trophic structure at hydrothermal and background sites in the Bransfield Strait to test the following hypotheses: (1) chemosynthetic organic matter will be an important food source in hydrothermal sediments; (2) siboglinid species subsist upon chemosynthetically derived $\mathrm{OM}$; (3) stable isotope signatures will reflect a priori functional designations defined by faunal morphology; and (4) fauna will have distinct niches between hydrothermal sites and background areas.

\section{Materials and methods}

\subsection{Sites and sampling}

Samples were collected during RRS James Cook cruise JC55 in the austral summer of 2011 (Tyler et al., 2011) from three raised edifices along the basin axis (Hook Ridge, the Three 


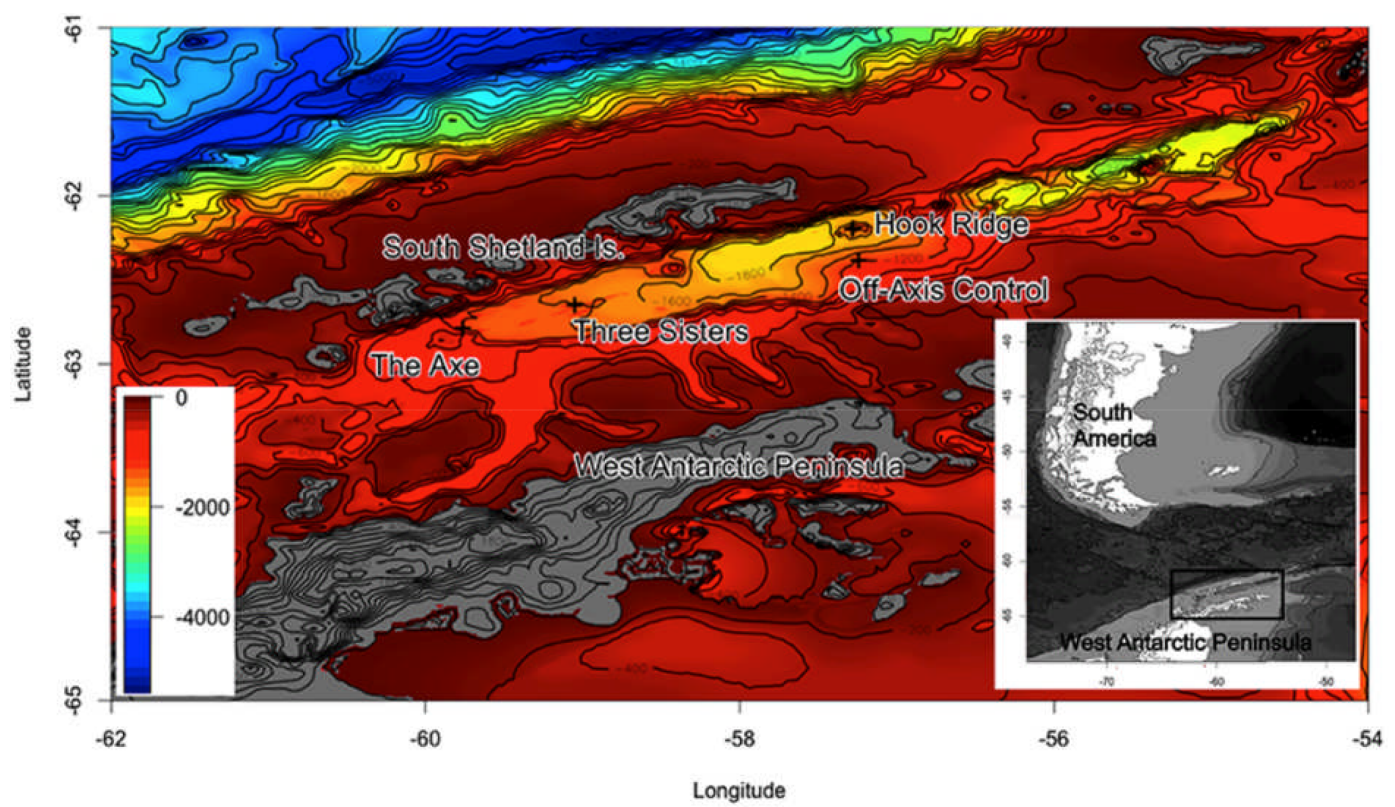

Figure 1. Sampling sites (after Bell et al., 2016b).

Table 1. Site descriptions and associated references.

\begin{tabular}{llll}
\hline Site & $\begin{array}{l}\text { Depth } \\
(\mathrm{m})\end{array}$ & $\begin{array}{l}\text { Hydrothermally } \\
\text { active? }\end{array}$ & References \\
\hline The Axe (AXE) & 1024 & No & Dählmann et al. (2001), \\
Off-vent (BOV) & 1150 & No & Klinkhammer et al. (2001), \\
Three Sisters (TS) & 1311 & No & Sahling et al. (2005), \\
Hook Ridge 1 (HR1) & 1174 & Low activity $\left(9 \mathrm{~cm} \mathrm{yr}^{-1}\right)$ & Aquilina et al. (2013, 2014), \\
Hook Ridge 2 (HR2) & 1054 & High activity $\left(34 \mathrm{~cm} \mathrm{yr}^{-1}\right)$ & Bell et al. (2016b) \\
\hline
\end{tabular}

Sisters, and the Axe) and one off-axis site in the Bransfield Strait (1024-1311m of depth; Fig. 1; Table 1). We visited two sites of variable hydrothermal activity (Hook Ridge 1 and 2) and three sites where hydrothermal activity was not detected (Three Sisters, the Axe, and an off-axis site; Aquilina et al., 2013). Of the two hydrothermal sites, Hook Ridge 2 had higher fluid advection rates and pore fluid temperature but lower concentrations of sulfide and methane (Dählmann et al., 2001; Aquilina et al., 2013, 2014).

Samples were collected with a Bowers and Connelly dampened megacorer (1024-1311 m of depth) and a single Agassiz trawl at Hook Ridge (1647 m of depth). With the exception of salps, all microbial and faunal samples presented here were from megacore deployments. For a detailed description of the megacore sampling programme and macrofaunal communities, see Bell et al. (2016b). Sampling consisted of 1-6 megacore deployments per site, with 2-5 cores pooled per deployment (Bell et al., 2016b). Cores were sliced into $0-5$ and $5-10 \mathrm{~cm}$ partitions and macrofauna were retained on a $300 \mu \mathrm{m}$ sieve. Residues were preserved in either $80 \%$ ethanol or $10 \%$ buffered formalin initially and then stored in $80 \%$ ethanol after sorting (Bell et al., 2016b). Fauna were sorted according to species or morphospecies level (for annelid and bivalve taxa), family level (for peracarids), and higher levels for less abundant phyla (e.g. echiurans). Salps were collected using an Agassiz trawl and samples were immediately picked and frozen at $-80^{\circ} \mathrm{C}$ and subsequently freeze-dried.

\subsection{Microbiology sequencing}

Samples of surface sediment $(0-1 \mathrm{~cm}$ below sea floor; cmb.s.f.) were taken from megacores at the two Hook Ridge sites and the off-axis site and frozen $\left(-80^{\circ} \mathrm{C}\right)$. DNA was extracted from the sediment by MR DNA (Shallowater, TX, USA) using an in-house standard 454 pipeline. The resultant sequences were trimmed and sorted using default methods in Geneious (v.9.1.5 with RDP v.2.8 and Krona v.2.0) and analysed in the Geneious $16 \mathrm{~S}$ Biodiversity Tool (https://16s.geneious.com/16s/help.html; Wang et al., 2007; Ondov et al., 2011; Kearse et al., 2012). 
Table 2. Differences in isotopic values and standard deviation $(\sigma)$ of ethanol-preserved fauna sampled during JC55 in response to acid treatment compared with population ranges of untreated samples. The Phyllodocida sp. was a single large specimen used only as part of preliminary experiments. Data rounded to $1 \mathrm{dp}$ to account for measurement error.

\begin{tabular}{llrrrr}
\hline Isotope & Species & Idoteidae sp. & Polycirrus sp. & Aphelochaeta glandaria & Phyllodocida sp. \\
\cline { 2 - 6 } & Treatment & $0.1 \mathrm{M} \mathrm{HCl}$ & $0.1 \mathrm{M} \mathrm{HCl}$ & $0.1 \mathrm{M} \mathrm{HCl}$ & $1.0 \mathrm{M} \mathrm{HCl}$ \\
\hline$\delta^{13} \mathrm{C}(\% \circ)$ & Difference in mean & 1.6 & 0.2 & 0.4 & 0.9 \\
& $\sigma$ untreated & 0.7 & 0.3 & 0.2 & 0.5 \\
& $\sigma$ treated & 0.7 & 0.3 & 0.2 & 0.2 \\
& Population range & 2.9 & 3.0 & 2.7 & - \\
\hline$\delta^{15} \mathrm{~N}(\% o)$ & Difference in mean & 0.9 & 0.2 & 0.1 & 0.9 \\
& $\sigma$ untreated & 0.2 & 0.3 & 0.2 & 0.4 \\
& $\sigma$ treated & 1.0 & 0.2 & 0.2 & 0.3 \\
& Population range & 3.4 & 4.6 & 5.8 & - \\
\hline$\delta^{34} \mathrm{~S}(\% o)$ & Difference in mean & - & - & 0.4 & 1.1 \\
& $\sigma$ untreated & - & - & 0.4 & 0.7 \\
& $\sigma$ treated & - & - & 2.3 & 1.4 \\
& Population range & - & - & & - \\
\hline
\end{tabular}

\subsection{Phospholipid fatty acids}

Samples of 3-3.5 g of freeze-dried sediment from Hook Ridge 1 and 2, the off-vent site, and the Three Sisters were analysed at the James Hutton Institute (Aberdeen, UK) following the procedure detailed in Main et al. (2015), as summarised below. Samples were from the top $1 \mathrm{~cm}$ of sediment for all sites except Hook Ridge 2 where sediment was pooled from two core slices $(0-2 \mathrm{~cm})$ due to sample mass limitations. Lipids were extracted following a method adapted from Bligh (1959) using a single-phase mixture of chloroform: methanol: citrate buffer $(1: 2: 0.8 v: v: v)$. Lipids were fractionated using $6 \mathrm{~mL}$ ISOLUTE SI SPE columns preconditioned with $5 \mathrm{~mL}$ of chloroform. Freeze-dried material was taken up in $400 \mu \mathrm{L}$ of chloroform, vortex mixed twice, and allowed to pass through the column. Columns were washed in chloroform and acetone (eluates discarded) and finally $10 \mathrm{~mL}$ of methanol. Eluates were collected, allowed to evaporate under an $\mathrm{N}_{2}$ atmosphere, and frozen $\left(-20^{\circ} \mathrm{C}\right)$.

Fatty acids were derivatised with methanol and $\mathrm{KOH}$ to produce fatty acid methyl esters (FAMEs). Samples were taken up in $1 \mathrm{~mL}$ of a $1: 1(v: v)$ mixture of methanol and toluene; $1 \mathrm{~mL}$ of $0.2 \mathrm{M} \mathrm{KOH}$ (in methanol) was added with a known quantity of an internal standard (C19:0, nonadecanoic acid), vortex mixed, and incubated at $37^{\circ} \mathrm{C}$ for $15 \mathrm{~min}$. After cooling to room temperature, $2 \mathrm{~mL}$ of isohexane : chloroform $(4: 1 v: v), 0.3 \mathrm{~mL}$ of $1 \mathrm{M}$ acetic acid, and $2 \mathrm{~mL}$ of deionised water was added to each vial. The solution was mixed and centrifuged, the organic phase was transferred to a new vial, and the remaining aqueous phase was mixed and centrifuged again to further extract the organic phase, which was combined with the previous. The organic phases were evaporated under an $\mathrm{N}_{2}$ atmosphere and frozen at $-20^{\circ} \mathrm{C}$.
Samples were taken up in isohexane to perform gas chromatography-combustion isotope ratio mass spectrometry (GC-C-IRMS). The quantity and $\delta^{13} \mathrm{C}$ values of individual FAMEs were determined using a GC Trace Ultra with a combustion column attached via a GC Combustion III to a Delta V Advantage isotope ratio mass spectrometer (Thermo Finnigan, Bremen). The $\delta^{13} \mathrm{C}_{\mathrm{VPDB}}$ values $(\% o)$ of each FAME were calculated with respect to a reference gas of $\mathrm{CO}_{2}$, traceable to IAEA reference material NBS 19 TS-Limestone. Measurement of the Indiana University reference material hexadecanoic acid methyl ester (certified $\delta^{13} \mathrm{C}_{\mathrm{VPDB}}-30.74 \pm 0.01 \%$ ) gave a value of $30.91 \pm 0.31 \%$ o (mean $\pm \mathrm{SD}, n=51$ ). Combined areas of all mass peaks $(\mathrm{m} / \mathrm{z} 44,45$ and 46$)$ following background correction were collected for each FAME. These areas relative to the internal C19:0 standard were used to quantify the 34 most abundant FAMEs and related to the FAs from which they are derived (Thornton et al., 2011).

Bacterial biomass was calculated using transfer functions from the total mass of four PLFAs (i14:0, i15:0, a15:0, and i16:0) estimated at $14 \%$ of total bacterial PLFA, which in turn is estimated at $5.6 \%$ of total bacterial biomass (Boschker and Middelburg, 2002).

\subsection{Bulk stable isotopes}

All bulk isotopic analyses were completed at the East Kilbride node of the Natural Environment Research Council Life Sciences Mass Spectrometry Facility. Specimens with carbonate structures (e.g. bivalves) were physically decarbonated and all specimens were rinsed in deionised water (e.g. to remove soluble precipitates such as sulfates) and cleaned of attached sediment before drying. Specimens were dried for at least $24 \mathrm{~h}$ at $50^{\circ} \mathrm{C}$ and weighed $(\mathrm{mg}$, correct 


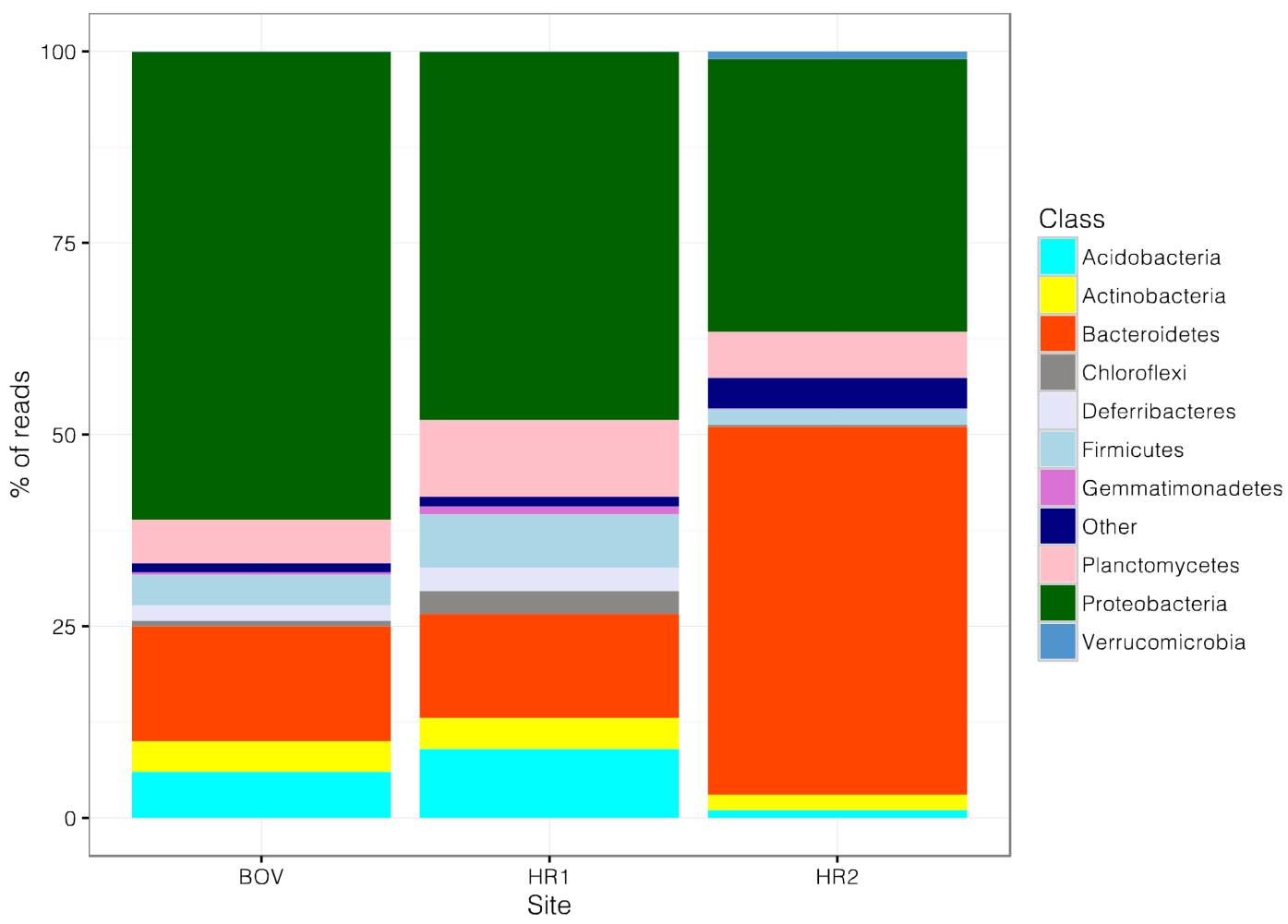

Figure 2. Microbial composition (classes) at the off-vent, off-axis site (BOV) and the two Hook Ridge sites (HR1 and HR2). Archaea excluded from figure as they only accounted for $0.008 \%$ of reads at HR2 and were not found elsewhere.

to $3 \mathrm{dp}$ ) into tin capsules and stored in a desiccator whilst awaiting SIA. Samples were analysed with a continuous-flow isotope ratio mass spectrometer using a vario PYRO cube elemental analyser (Elementar) coupled with a Delta Plus $\mathrm{XP}$ isotope ratio mass spectrometer (Thermo Electron). Each of the runs of $\mathrm{CN}$ and CNS isotope analyses used laboratory standards (gelatin and two amino acid-gelatin mixtures) and the international standard USGS40 (glutamic acid). CNS measurements used the internal standards (MSAG2: (methanesulfonamide-gelatin and M1: methionine) and the international silver sulfide standards IAEA-S1, IAEA-S2, and IAEA-S3. All sample runs included samples of freezedried, powdered Antimora rostrata (ANR), an external reference material used in other studies of chemosynthetic ecosystems (Reid et al., 2013; Bell et al., 2016a) to monitor variation between runs and instruments (Supplement S1). Instrument precision (SD) for each isotope measured from ANR was $0.42,0.33$, and $0.54 \%$ o for carbon, nitrogen, and sulfur, respectively. The reference samples were generally consistent except in one of the CNS runs, which showed unusual $\delta^{15} \mathrm{~N}$ measurements (Supplement $\mathrm{S} 1$ ), so faunal $\delta^{15} \mathrm{~N}$ measurements from this run were excluded as a precaution. Stable isotope ratios are all reported in delta $(\delta)$ per mil $(\% o)$ notation relative to international standards: VPDB $\left(\delta^{13} \mathrm{C}\right)$, air $\left(\delta^{15} \mathrm{~N}\right)$, and VCDT $\left(\delta^{34} \mathrm{~S}\right)$. Machine error relative to these standards ranged from $0.01-0.23$ for $\delta^{13} \mathrm{C}, 0.01-0.13$ for $\delta^{15} \mathrm{~N}$, and $0.13-3.04$ for $\delta^{34} \mathrm{~S}$. One of the sulfur standards $\left(\mathrm{Ag}_{2} \mathrm{~S}\right.$ IAEA, Supplement Sect. S2) had a notable difference from the agreed measurements, suggesting either a compromised standard or poor instrument precision. This error was not observed in other standards or the reference material used, but given the uncertainty here only $\delta^{34} \mathrm{~S}$ differences greater than $3 \%$ are considered as significant.

A combination of dual-isotope $\left(\delta^{13} \mathrm{C}\right.$ and $\delta^{15} \mathrm{~N} ; 319$ samples) and tri-isotope $\left(\delta^{13} \mathrm{C}, \delta^{15} \mathrm{~N}\right.$ and $\delta^{34} \mathrm{~S} ; 83$ samples $)$ techniques was used to describe bulk isotopic signatures of 43 species of macrofauna (35 from non-hydrothermal sites, 19 from hydrothermal sites, and 11 from both) and 3 megafaunal taxa and sources of organic matter. Samples submitted for carbon and nitrogen $(\mathrm{CN})$ analyses were pooled if necessary to achieve an optimal mass of $0.7 \mathrm{mg}$ $( \pm 0.5 \mathrm{mg})$. Where possible, individual specimens were kept separate in order to preserve variance structure within populations, but in some cases low sample mass meant individuals had to be pooled (from individuals found in replicate deployments). Optimal mass for tri-isotope (CNS) measurements was $2.5 \mathrm{mg}( \pm 0.5 \mathrm{mg})$ and, as with $\mathrm{CN}$ analyses, specimens were preferentially submitted as individual samples or pooled if necessary. Samples of freeze-dried sediment from each site were also submitted for CNS analyses (untreated for $\mathrm{NS}$ and acidified with $6 \mathrm{M} \mathrm{HCl}$ for $\mathrm{C}$ ). Acidification was 
Table 3. Most dominant bacterial genera (covering the top five at each site), with percent of total sequenced reads.

\begin{tabular}{llrrr}
\hline Genera & Class & Off-vent & Hook Ridge & Hook Ridge \\
& & $\%$ & $1 \%$ & $2 \%$ \\
\hline Aestuariicola & Flavobacteria & 1.37 & 0.53 & 6.89 \\
Arenicella & Gammaproteobacteria & 7.14 & 5.17 & 2.24 \\
Blastopirellula & Planctomycetacia & 2.50 & 3.01 & 1.92 \\
Denitrovibiro & Deferribacteres & 1.72 & 2.54 & 0.27 \\
Geothermobacter & Deltaproteobacteria & 2.40 & 1.90 & 0.52 \\
Lutimonas & Flavobacteria & 0.45 & 0.42 & 4.87 \\
Maritimimonas & Flavobacteria & 1.10 & 0.15 & 4.32 \\
Methylohalomonas & Gammaproteobacteria & 4.29 & 2.78 & 2.08 \\
Pasteuria & Bacilli & 3.30 & 5.02 & 1.67 \\
Tenacibaculum & Flavobacteria & 0.26 & 0.04 & 3.36 \\
Winogradskyella & Flavobacteria & 0.99 & 0.90 & 4.09 \\
\hline
\end{tabular}

carried out by repeated washing with acid and deionised water.

Specimens were not acidified. A pilot study and the subsequent results presented here confirm that the $\delta^{13} \mathrm{C}$ measurements $(0.1$ and $1.0 \mathrm{M} \mathrm{HCl})$ were within the untreated population range in both polychaetes and peracarids and that acidification did not notably or consistently reduce $\delta^{13} \mathrm{C}$ standard deviation (Table 2). In the absence of a large or consistent treatment effect, the low sample mass (particularly for CNS samples) was dedicated to increasing replication and preserving the integrity of $\delta^{15} \mathrm{~N}$ and $\delta^{34} \mathrm{~S}$ measurements instead of separating carbon and nitrogen-sulfur samples (Connolly and Schlacher, 2013).

Formalin and ethanol preservation effects can both influence the isotopic signature of a sample (Fanelli et al., 2010; Rennie et al., 2012). Taxa that had several samples of each preservation method from a single site (to minimise intraspecific differences) were examined to determine the extent of isotopic shifts associated with preservation effects. Carbon and nitrogen isotopic differences between ethanol- and formalin-preserved samples ranged from $0.1-1.4 \%$ and $0.4-$ $2.0 \%$, respectively. Differences across all samples were not significant (paired $t$ test, ${ }^{13} \mathrm{C}: t=2.10, \mathrm{~d} f=3, p=0.126$; $\left.\delta^{15} \mathrm{~N}: t=1.14, \mathrm{~d} f=3, p=0.337\right)$. Given the unpredictable response of isotopic signatures to preservation effects (which also cannot be extricated from within-site, intraspecific variation), it was not possible to correct isotopic data (Bell et al., 2016a). This contributed an unavoidable but generally quite small source of error in these measurements.

\subsection{Statistical analyses}

All analyses were completed in the $\mathrm{R}$ statistical environment (R Core Team, 2013). CN stable isotopic measurements were divided into those from hydrothermal and non-hydrothermal sites, averaged by taxa, and used to construct a Euclidean distance matrix (Valls et al., 2014). A similarity profile routine (SIMPROF, 10000 permutations, $p=0.05$, Ward linkage) was applied to the distance matrix in the clustsig package (v1.0) (Clarke et al., 2008; Whitaker and Christmann, 2013) to detect significant structure. The resulting cluster assignations were compared to a priori feeding groups (Bell et al., 2016b) using a Spearman correlation test (with 9999 Monte Carlo resamplings) in the coin package (v1.0-24; Hothorn et al., 2015). Isotopic signatures of species sampled from both hydrothermal and non-hydrothermal sites were also compared with a one-way ANOVA with Tukey's HSD pairwise comparisons (following a Shapiro-Wilk normality test).

Mean faunal measurements of $\delta^{13} \mathrm{C}$ and $\delta^{15} \mathrm{~N}$ were used to calculate Layman metrics for each site (Layman et al., 2007), sample-size-corrected standard elliptical area (SEAc), and Bayesian posterior draws (SEA.B, mean of $10^{5}$ draws $\pm 95 \%$ credibility interval) in the SIAR package (v4.2) (Parnell et al., 2010; Jackson et al., 2011). Differences in SEA.B between sites were compared in mixSIAR. The value of $p$ given is the proportion of ellipses from group A that were smaller in area than those from group B (e.g. if $p=0.02$, then $2 \%$ of posterior draws from group A were smaller than the group B mean) and is considered to be a semi-quantitative measure of difference in means (Jackson et al., 2011).

\section{Results}

\subsection{Differences in microbial composition along a hydrothermal gradient}

A total of 28767,35490 , and 47870 sequences were obtained from the off-axis site and the hydrothermal sites Hook Ridge 1 and 2, respectively. Bacteria comprised almost the entirety of each sample, with Archaea being detected only in the Hook Ridge 2 sample ( $<0.1 \%$ of sequences; Fig. 2). Hook Ridge 1 was qualitatively more similar to the off-axis site than Hook Ridge 2. Both Hook Ridge 1 (hydrothermal) and the off-vent site were dominated by Proteobacteria (48 and $61 \%$ of reads, respectively; Fig. 2), whereas Flavobacteriia dominated Hook Ridge 2 (43\%; 7-12\% elsewhere) 
Table 4. PLFA profiles from freeze-dried sediment (nM per g dry sediment). PLFA names relate to standard notation (i: iso; a: anti-iso; first number: number of carbon atoms in chain; $\omega=$ : double bond; Me: methyl group).

\begin{tabular}{|c|c|c|c|c|c|c|}
\hline \multirow[b]{2}{*}{ PLFA } & \multicolumn{3}{|c|}{ Bransfield off-vent } & \multicolumn{3}{|c|}{ Three Sisters } \\
\hline & $\mathrm{nMg}^{-1}$ & $\%$ & $\delta^{13} \mathrm{C}(\% \circ)$ & $\mathrm{nM} \mathrm{g}^{-1}$ & $\%$ & $\delta^{13} \mathrm{C}(\% \circ)$ \\
\hline i14:0 & 0.03 & 0.12 & -22.0 & 0.02 & 0.09 & -28.0 \\
\hline $14: 0$ & 0.80 & 3.04 & -31.2 & 0.83 & 3.43 & -30.9 \\
\hline i15:0 & 0.76 & 2.89 & -28.6 & 0.76 & 3.13 & -28.1 \\
\hline a15:0 & 1.06 & 4.03 & -28.4 & 1.06 & 4.39 & -27.7 \\
\hline $15: 0$ & 0.30 & 1.13 & -29.3 & 0.19 & 0.77 & -29.8 \\
\hline i16:1 & 0.11 & 0.44 & -31.4 & 0.02 & 0.10 & -20.3 \\
\hline $16: 1 w 11 \mathrm{c}$ & 0.00 & 0.00 & n.d. & 0.06 & 0.24 & -23.1 \\
\hline i16:0 & 0.34 & 1.30 & -28.5 & 0.30 & 1.24 & -27.8 \\
\hline $16: 1 \mathrm{w} 11 \mathrm{t}$ & 0.78 & 2.98 & -24.4 & 0.66 & 2.75 & -25.0 \\
\hline $16: 1 w 7 c$ & 3.98 & 15.19 & -28.9 & 3.37 & 13.95 & -28.1 \\
\hline $16: 1 w 5 c$ & 1.12 & 4.27 & -34.1 & 0.96 & 3.99 & -34.0 \\
\hline $16: 0$ & 4.29 & 16.37 & -31.1 & 3.80 & 15.73 & -30.0 \\
\hline br17:0 & 0.00 & 0.00 & n.d. & 0.00 & 0.00 & n.d. \\
\hline 10-Me-16:0 & 0.46 & 1.77 & -28.5 & 0.45 & 1.87 & -29.1 \\
\hline i17:0 & 0.08 & 0.32 & -33.2 & 0.20 & 0.84 & -29.8 \\
\hline a17:0 & 0.25 & 0.97 & -31.9 & 0.21 & 0.87 & -31.3 \\
\hline 12-Me-16:0 & 0.25 & 0.94 & -32.9 & 0.21 & 0.86 & -31.6 \\
\hline $17: 1 w 8 c$ & 0.13 & 0.50 & -34.1 & 0.11 & 0.44 & -31.3 \\
\hline 17:0cy & 0.33 & 1.26 & -36.2 & 0.27 & 1.10 & -32.8 \\
\hline $17: 0$ & 0.15 & 0.56 & -40.0 & 0.08 & 0.33 & -50.4 \\
\hline $10-\mathrm{Me}-17: 0$ & 0.00 & 0.00 & n.d. & 0.00 & 0.00 & n.d. \\
\hline $18: 3 w 6,8,13$ & 0.67 & 2.55 & -34.6 & 0.69 & 2.87 & -33.8 \\
\hline $18: 2 w 6,9$ & 0.12 & 0.46 & -27.8 & 0.09 & 0.36 & -52.2 \\
\hline 18:1w9 & 1.13 & 4.30 & -30.0 & 1.33 & 5.50 & -29.9 \\
\hline 18:1w7 & 4.42 & 16.85 & -29.0 & 3.84 & 15.91 & -29.1 \\
\hline $18: 1 w(10$ or 11$)$ & 2.33 & 8.88 & -30.1 & 2.26 & 9.36 & -29.9 \\
\hline $18: 0$ & 0.66 & 2.50 & -30.6 & 0.54 & 2.22 & -30.6 \\
\hline 19:1w6 & 0.03 & 0.12 & -23.5 & 0.03 & 0.12 & -30.1 \\
\hline 10-Me-18:0 & 0.00 & 0.00 & n.d. & 0.00 & 0.00 & n.d. \\
\hline $19: 1 w 8$ & 0.11 & 0.42 & -56.6 & 0.17 & 0.69 & -37.5 \\
\hline 19:0cy & 0.20 & 0.77 & -35.6 & 0.20 & 0.83 & -34.8 \\
\hline $20: 4(n-6)$ & 0.14 & 0.55 & -40.0 & 0.20 & 0.83 & -34.1 \\
\hline $20: 5(n-3)$ & 0.41 & 1.57 & -38.0 & 0.30 & 1.23 & -39.3 \\
\hline $20: 1(n-9)$ & 0.42 & 1.60 & -31.5 & 0.41 & 1.71 & -33.7 \\
\hline $22: 6(n-3)$ & 0.22 & 0.83 & -34.1 & 0.43 & 1.77 & -30.0 \\
\hline $22: 1(n-9)$ & 0.10 & 0.39 & -31.3 & 0.10 & 0.41 & -29.9 \\
\hline $24: 1(n-9)$ & 0.03 & 0.12 & -28.7 & 0.02 & 0.07 & -29.7 \\
\hline Total & 26.23 & & & 24.15 & & \\
\hline Average & 0.71 & & -30.5 & 0.65 & & -30.1 \\
\hline & & $\mathrm{mg} \mathrm{C} \mathrm{m}{ }^{-2}$ & $\delta^{13} \mathrm{C}(\% \circ)$ & & $\mathrm{mg} \mathrm{Cm}^{-2}$ & $\delta^{13} \mathrm{C}(\% \circ)$ \\
\hline Bacterial biomass & & 134.50 & -26.8 & & 197.12 & -26.4 \\
\hline
\end{tabular}


Table 4. Continued.

\begin{tabular}{|c|c|c|c|c|c|c|}
\hline \multirow[b]{2}{*}{ PLFA } & \multicolumn{2}{|c|}{ Hook Ridge 1} & \multicolumn{3}{|c|}{ Hook Ridge 2} & \multirow{2}{*}{$\begin{array}{r}\text { Range } \\
\delta^{13} \mathrm{C}(\% o)\end{array}$} \\
\hline & $\mathrm{nMg}^{-1}$ & $\delta^{13} \mathrm{C}(\% \circ)$ & $\mathrm{nMg}^{-1}$ & $\%$ & $\delta^{13} \mathrm{C}(\% \circ)$ & \\
\hline i14:0 & 0.03 & -15.7 & 0.10 & 0.80 & -28.8 & -13.1 \\
\hline 14:0 & 0.80 & -32.7 & 0.80 & 6.40 & -29.6 & -3.1 \\
\hline i15:0 & 0.76 & -29.7 & 0.40 & 3.20 & -28.1 & -1.7 \\
\hline a15:0 & 1.06 & -29.1 & 0.90 & 7.20 & -28.9 & -1.4 \\
\hline $15: 0$ & 0.30 & -29.0 & 0.30 & 2.40 & -28.3 & -1.5 \\
\hline i16:1 & 0.11 & -27.6 & 0.00 & 0.00 & n.d. & -11.1 \\
\hline $16: 1 \omega 11 \mathrm{c}$ & 0.00 & -17.4 & 0.00 & 0.00 & n.d. & -5.7 \\
\hline $\mathrm{i} 16: 0$ & 0.34 & -29.4 & 0.20 & 1.60 & -28.8 & -1.6 \\
\hline $16: 1 \omega 11 \mathrm{t}$ & 0.78 & -25.8 & 0.30 & 2.40 & -8.7 & -17.2 \\
\hline $16: 1 \omega 7 \mathrm{c}$ & 3.98 & -29.2 & 2.50 & 20.00 & -22.9 & -6.3 \\
\hline $16: 1 \omega 5 \mathrm{c}$ & 1.12 & -31.2 & 0.30 & 2.40 & -24.3 & -9.7 \\
\hline 16:0 & 4.29 & -31.8 & 3.30 & 26.40 & -29.3 & -2.5 \\
\hline br17:0 & 0.00 & -22.9 & 0.00 & 0.00 & -15.8 & -7.2 \\
\hline 10-Me-16:0 & 0.46 & -30.3 & 0.20 & 1.60 & -41.3 & -12.8 \\
\hline i17:0 & 0.08 & n.d. & 0.00 & 0.00 & n.d. & -3.4 \\
\hline a17:0 & 0.25 & -29.0 & 0.20 & 1.60 & -28.6 & -3.4 \\
\hline 12-Me-16:0 & 0.25 & -28.6 & 0.10 & 0.80 & -28.2 & -4.7 \\
\hline $17: 1 \omega 8 \mathrm{c}$ & 0.13 & -27.1 & 0.10 & 0.80 & -27.2 & -6.9 \\
\hline 17:0cy & 0.33 & -32.3 & 0.20 & 1.60 & -27.7 & -8.5 \\
\hline $17: 0$ & 0.15 & -40.0 & 0.20 & 1.60 & -30.8 & -19.6 \\
\hline 10-Me-17:0 & 0.00 & -35.0 & 0.00 & 0.00 & n.d. & 0.00 \\
\hline $18: 3 \omega 6,8,13$ & 0.67 & -31.2 & 0.50 & 4.00 & -29.0 & -5.6 \\
\hline $18: 2 \omega 6,9$ & 0.12 & -30.0 & 0.30 & 2.40 & -26.7 & -25.5 \\
\hline $18: 1 \omega 9$ & 1.13 & -29.6 & 0.40 & 3.20 & -25.6 & -4.4 \\
\hline $18: 1 w 7$ & 4.42 & -29.9 & 0.60 & 4.80 & -24.7 & -5.1 \\
\hline $18: 1 \omega(10$ or 11$)$ & 2.33 & -31.9 & 0.00 & 1.60 & n.d. & -2.0 \\
\hline $18: 0$ & 0.66 & -29.4 & 0.30 & 0.00 & -29.9 & -1.2 \\
\hline $19: 1 \omega 6$ & 0.03 & -26.2 & 0.00 & 2.40 & n.d. & -6.6 \\
\hline 10-Me-18:0 & 0.00 & -25.4 & 0.00 & 0.00 & n.d. & 0.0 \\
\hline $19: 1 \omega 8$ & 0.11 & -41.2 & 0.00 & 0.00 & n.d. & -19.1 \\
\hline 19:0cy & 0.20 & -30.5 & 0.10 & 0.00 & -28.7 & -6.9 \\
\hline $20: 4(n-6)$ & 0.14 & n.d. & 0.00 & 0.80 & n.d. & -5.9 \\
\hline $20: 5(n-3)$ & 0.41 & n.d. & 0.00 & 0.00 & n.d. & -1.3 \\
\hline $20: 1(n-9)$ & 0.42 & n.d. & 0.00 & 0.00 & n.d. & -2.2 \\
\hline $22: 6(n-3)$ & 0.22 & n.d. & 0.00 & 0.00 & n.d. & -4.2 \\
\hline $22: 1(n-9)$ & 0.10 & n.d. & 0.00 & 0.00 & n.d. & -1.4 \\
\hline $24: 1(n-9)$ & 0.03 & n.d. & 0.00 & 0.00 & n.d. & -1.0 \\
\hline Total & 26.23 & & 12.30 & & & \\
\hline \multirow[t]{2}{*}{ Average } & 0.71 & -30.3 & 0.33 & & -26.9 & \\
\hline & $\mathrm{mg} \mathrm{Cm}^{-2}$ & $\delta^{13} \mathrm{C}(\% \circ)$ & & $\mathrm{mg} \mathrm{Cm}^{-2}$ & $\delta^{13} \mathrm{C}(\% \circ)$ & \\
\hline Bacterial biomass & 534.55 & -26.6 & & 85.45 & -23.1 & \\
\hline
\end{tabular}

N.P. indicates "not present" in sample. Total PLFA $\delta^{13} \mathrm{C}$ measurements weighted by concentration. Bulk bacterial $\delta^{13} \mathrm{C}$ estimated from average conversion factor of 3.7\%o (Boschker and Middelburg, 2002). The notation n.d. indicates "no data". Range measurements may be subject to rounding error.

with Proteobacteria accounting for a smaller percentage of sequences (36\%; Fig. 2). By sequence abundance, Flavobacteriia were the most clearly disparate group between Hook Ridge 2 and the other sites. Flavobacteriia were comprised of 73 genera at Hook Ridge 2, 60 genera at BOV, and 63 genera at HR1, of which 54 genera were shared between all sites. Hook Ridge 2 had 15 unique flavobacteriial genera, but these collectively accounted for just $0.9 \%$ of reads, indicating that compositional differences were mainly driven by relative abundance rather than taxonomic richness.

The most abundant genus from each site was Arenicella at BOV and HR1 (7.1 and 5.2\% of reads, respectively) and 
Aestuariicola at HR2 (6.9\% of reads; Table 3). The four most abundant genera at both BOV and HR1 were Arenicella $(\gamma$-Proteobacteria), Methylohalomonas ( $\gamma$-Proteobacteria), Pasteuria (Bacilli), and Blastopirellula (Planctomycetacia), though not in the same order, and accounted for 17.2 and $16.0 \%$ of reads, respectively. The four most abundant genera at HR2, accounting for $20.2 \%$ of reads, were Aestuariicola, Lutimonas, Maritimimonas, and Winogradskyella (Flavobacteriia). The genera Arenicella and Pasteuria were the most relatively abundant across all sites $(2.2-7.1 \%$ and $1.7-5.0 \%$ of reads, respectively; Table 3 ).

\subsection{Microbial fatty acids}

A total of 37 sedimentary FAs were identified across all sites in individual abundances ranging between 0 and $26.4 \%$ of total FA (Table 4; Supplement Fig. S1, Bell et al., 2017b). All lipid samples were dominated by saturated and monounsaturated fatty acids (SFAs and MUFAs), comprising 91-94\% of FA abundance per site. The most abundant FAs at each site were $16: 0(15.7-26.4 \%), 16: 1 \omega 7 \mathrm{c}(11.5-20.0 \%)$, and 18:1 $\omega 7$ (4.8-16.9\%; Table 4). PLFA profiles from each of the non-hydrothermal sites sampled (off-axis and the Three Sisters, 33 and 34 FAs, respectively) were quite similar (Table 4) and shared all but one compound $(16: 1 \omega 11 \mathrm{c}$, present only at the non-hydrothermal Three Sisters site). Fewer FAs were enumerated from Hook Ridge 1 and 2 (31 and 23, respectively), including 3 FAs not observed at the nonhydrothermal sites (br17:0, 10-Me-17:0, and 10-Me-18:0), which accounted for $0.5-1.2 \%$ of the total at these sites. Polyunsaturated algal biomarkers (20:5 $\omega 3$ and 22:6 $\omega 3$ ) were only detected at the non-hydrothermal site $(0.83-1.57 \%$ of total FA abundance). Hook Ridge 2 had the lowest number of FAs and the lowest total FA biomass of any site, though this was due in part to the fact that this sample had to be pooled from the top $2 \mathrm{~cm}$ of sediment (top $1 \mathrm{~cm}$ at other sites). Bacterial biomass was highest at Hook Ridge 1 and ranged from $85-535 \mathrm{mg} \mathrm{C} \mathrm{m}^{-2}$ (Table 3).

PLFA carbon isotopic signatures ranged from -56 to $-20 \%$ at non-hydrothermal sites and -42 to $-8 \%$ at hydrothermal sites (Table 4). Weighted average $\delta^{13} \mathrm{C}$ values were quite similar between the non-hydrothermal sites and Hook Ridge 1 ( -30.5 and $-30.1 \%$, respectively), but were heavier at Hook Ridge $2(-26.9 \%$; Table 4$)$. Several of the FAs identified had a large range in $\delta^{13} \mathrm{C}$ between samples (including $16: 1 \omega 11 \mathrm{t} \delta^{13} \mathrm{C}$, range $17.2 \%$ and $19: 1 \omega 8$ $\delta^{13} \mathrm{C}$, range $19.1 \%$ ), even between the non-hydrothermal

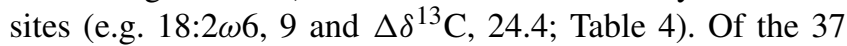
FAs, 7 had a $\delta^{13} \mathrm{C}$ range of $>10 \%$ but these were comparatively minor and individually accounted for $0-4.9 \%$ of total abundance. Average $\delta^{13} \mathrm{C}$ range was $6.3 \%$ and a further 11 FAs had a $\delta^{13} \mathrm{C}$ range of $>5 \%$, including some of the more abundant FAs, accounting for $36.8-46.6 \%$ at each site. FAs with small $\delta^{13} \mathrm{C}$ ranges $(<5 \%$ ) accounted for $44.6-54.4 \%$ of total abundance at each site.
Table 5. Mean isotopic signatures of sediment organic matter.

\begin{tabular}{lrrl}
\hline Isotope & $\begin{array}{r}\text { Hydrothermal } \\
\text { sites \%o }( \pm \mathrm{SD})\end{array}$ & $\begin{array}{r}\text { Non-hydrothermal } \\
\text { sites \%o }( \pm \mathrm{SD})\end{array}$ & $\begin{array}{l}\text { Different? } \\
(t \text { test, } \mathrm{d} f=3)\end{array}$ \\
\hline$\delta^{13} \mathrm{C}$ & $-26.2( \pm 0.4)$ & $-25.8( \pm 0.3)$ & No \\
$\delta^{15} \mathrm{~N}$ & $5.7( \pm 0.7)$ & $5.0( \pm 0.3)$ & No \\
$\delta^{34} \mathrm{~S}$ & $14.3( \pm 2.9)$ & $19.4( \pm 0.6)$ & Yes $(t=3.49$, \\
& & & $p<0.05)$ \\
\hline
\end{tabular}

\subsection{Description of bulk isotopic signatures}

Most faunal isotopic signatures were within a comparatively narrow range $\left(\delta^{13} \mathrm{C}:-30\right.$ to $-20 \%, \delta^{15} \mathrm{~N}$ : 5 to $15 \%$, and $\delta^{34} \mathrm{~S}$ : 10 to $20 \%$ ) and more depleted isotopic signatures were usually attributable to siboglinid species (Fig. 3; Bell et al., 2017b). The Siboglinum spp. (found at all nonhydrothermal sites) had mean $\delta^{13} \mathrm{C}$ and $\delta^{15} \mathrm{~N}$ values of -41.4 and $-8.9 \%$, respectively, and Sclerolinum contortum (predominately from Hook Ridge 1 but found at both hydrothermal sites) had values of -20.5 and $-5.3 \%$, respectively. Some non-endosymbiont-bearing taxa (e.g. macrofaunal neotanaids from the off-axis site and megafaunal ophiuroids at Hook Ridge 2) also had notably depleted $\delta^{15} \mathrm{~N}$ signatures (means -3.6 to $2.6 \%$, respectively; Fig. 3).

Isotopic signatures of sediment organic matter were similar between hydrothermal and non-hydrothermal sites for $\delta^{13} \mathrm{C}$ and $\delta^{15} \mathrm{~N}$ but $\delta^{34} \mathrm{~S}$ was significantly greater at nonhydrothermal sites ( $p<0.05$, Table 5; Fig. 4). Variability was higher in hydrothermal sediments for all isotopic signatures. Faunal isotopic signatures for $\delta^{13} \mathrm{C}$ and $\delta^{34} \mathrm{~S}$ ranged much more widely than sediment signatures and indicate that sediment organics were a mixture of two or more sources of organic matter. A few macrofaunal species had relatively heavy $\delta^{13} \mathrm{C}$ signatures that exceeded $-20 \%$, suggesting either a heavy source of carbon or marine carbonate in residual exoskeletal tissue, particularly for peracarids $(\sim 0 \%$ ). Samples of pelagic salps from Hook Ridge had mean values for $\delta^{13} \mathrm{C}$ of $-27.4 \% o( \pm 0.9)$ and for $\delta^{34} \mathrm{~S}$ of $21.5 \% \circ( \pm 0.8)$.

\subsection{Comparing macrofaunal morphology and stable isotopic signatures}

Isotopic data (mean of each species for $\delta^{13} \mathrm{C}, \delta^{15} \mathrm{~N}$, and $\delta^{34} \mathrm{~S}$ ) were used to construct a Euclidean distance matrix and the resultant hierarchy was compared to classifications based upon morphology. Species were assigned to one of four clusters (SIMPROF, $p=0.05$; Fig. S3). No significant correlation between a priori (based on morphology) and a posteriori cluster assignations (based on isotopic data) was detected (Spearman correlation test: $Z=-1.34 ; N=43 ; p=0.18$ ). Clusters were mainly discriminated based on $\delta^{15} \mathrm{~N}$ values, and peracarids were the only taxa to be represented in all of the clusters, indicating relatively high trophic diversity. 

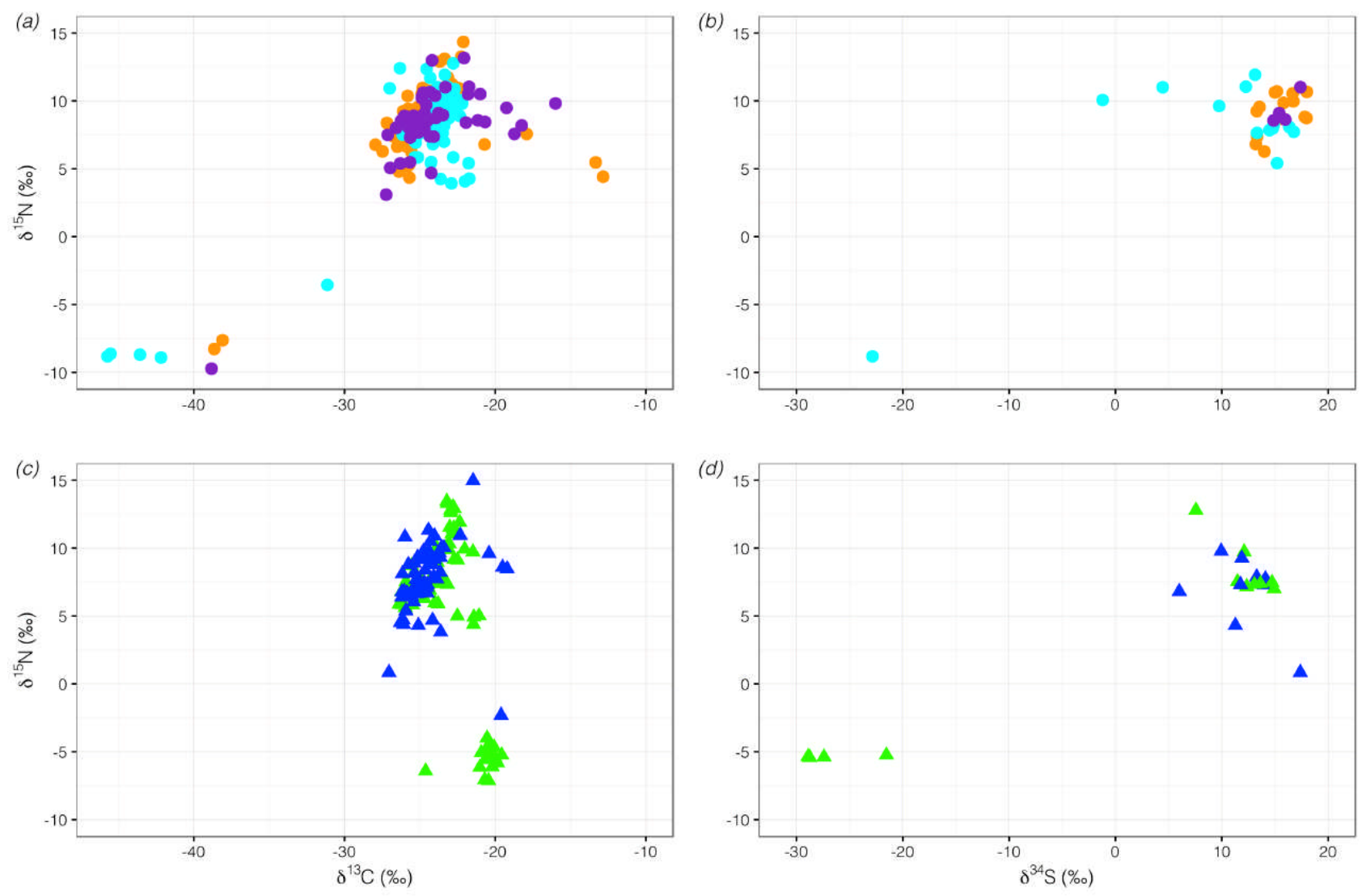

- The Axe Off-vent $\bullet$ Three Sisters $\mathbf{A}$ Hook Ridge 1 a Hook Ridge 2

Figure 3. Carbon-nitrogen and sulfur-nitrogen biplots for bulk isotopic signatures of benthos separated into non-hydrothermal (a, b) and hydrothermal sites (c, d). Except for one value from the off-vent site (for a peracarid species), all values with $\delta^{15} \mathrm{~N}$ of $<0$ were siboglinid species (Sclerolinum contortum from the hydrothermal sites and Siboglinum spp. from the non-hydrothermal sites).

Several taxa found at both hydrothermal and nonhydrothermal sites were assigned to different clusters between sites. A total of 11 taxa were sampled from both hydrothermal and non-hydrothermal regions, of which 4 were assigned to different clusters at hydrothermal and nonhydrothermal sites. Neotanaids (Peracarida: Tanaidacea) had the greatest Euclidean distance between hydrothermal and non-hydrothermal samples (11.36), demonstrating clear differences in dietary composition (Fig. 5). All other species were separated by much smaller distances between regions (range: 0.24 to 2.69 ). Raw $\delta^{13} \mathrm{C}$ and $\delta^{15} \mathrm{~N}$ values were also compared between hydrothermal and non-hydrothermal samples for each species (one-way ANOVA with Tukey HSD pairwise comparisons). Analysis of the raw data indicated that $\delta^{13} \mathrm{C}$ signatures were different for neotanaids only and $\delta^{15} \mathrm{~N}$ signatures were different for neotanaids and an oligochaete species (Limnodriloides sp.; ANOVA, $p<0.01$; Fig. 5).

\subsection{Community-level trophic metrics}

All site niches overlapped (mean 50, range 30-82\%) and the positions of ellipse centroids were broadly similar for all sites (Table 6; Fig. 6). Hydrothermal site ellipse areas were similar but significantly smaller than non-hydrothermal ellipses (SEA.B, $n=10^{5}, p=<0.05$ ). There were no significant differences in ellipse area between any of the nonhydrothermal sites. Ranges in carbon sources $(\mathrm{dCr})$ were higher for non-hydrothermal sites (Table 6), indicating a greater trophic diversity in background conditions. Nitrogen range (dNr; Table 6) was similar between hydrothermal and non-hydrothermal sites, suggesting a similar number of trophic levels within each assemblage. All site ellipses had broadly similar eccentricity (degree of extension along long axis) ranging from 0.85 to 0.97 (Table 6); however, theta (angle of long axis) differed between hydrothermal and non-hydrothermal sites ( -1.43 to 1.55 at Hook Ridge, 0.67 to 0.86 at non-hydrothermal sites). The range in nitrogen sources was more influential at hydrothermal sites than Sclerolinum contortum, which had very low $\delta^{15} \mathrm{~N}$ signatures but similar $\delta^{13} \mathrm{C}$ values when compared with non-endosymbiont- 


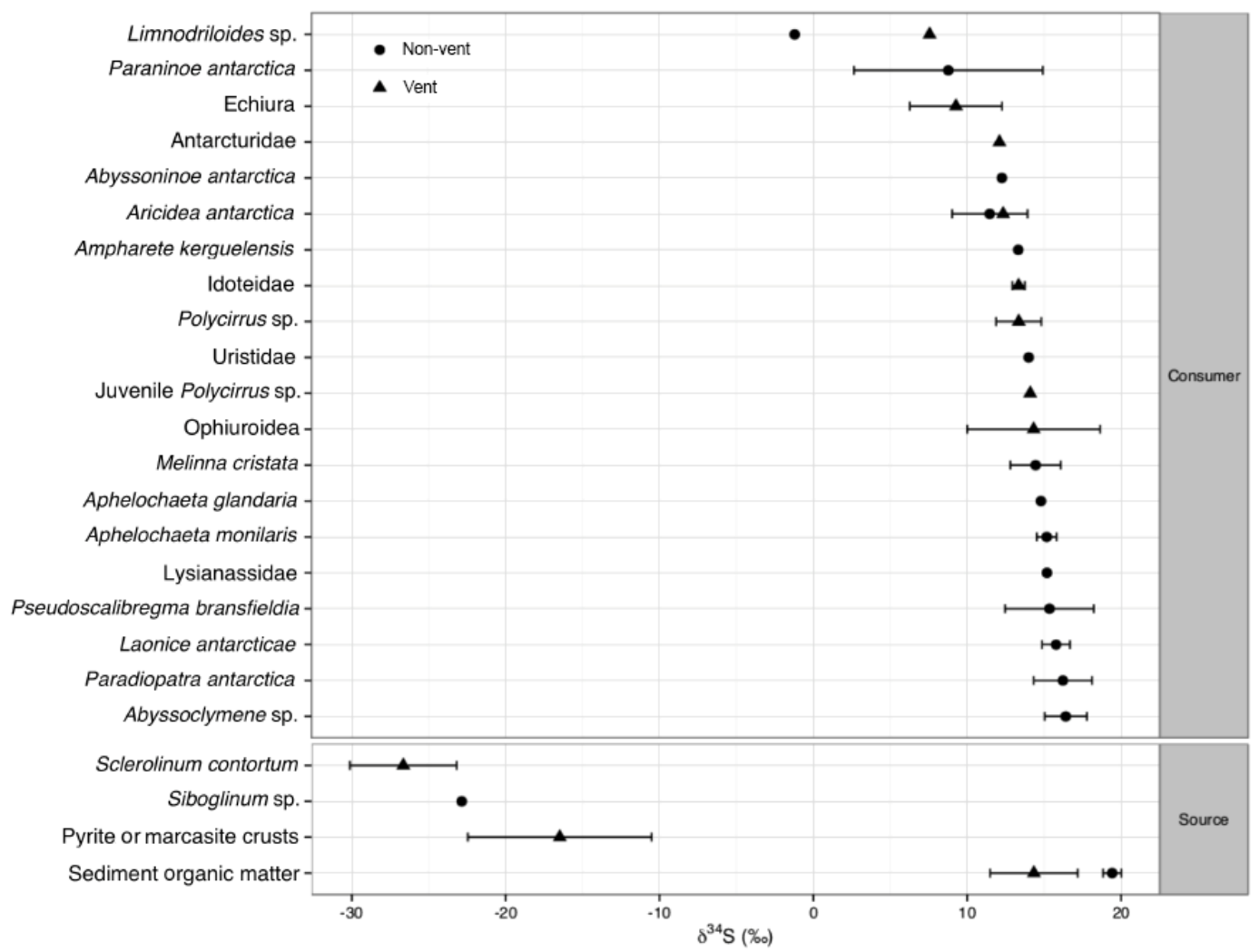

Figure 4. Plot of $\delta^{34} \mathrm{~S}$ measurements discriminated by species and habitat (hydrothermally active vents and sediments or non-hydrothermally active sediments $\pm 1 \mathrm{SD}$ ). Data for $\delta^{34} \mathrm{~S}$ in crusts from Petersen et al. (2004).

bearing taxa from the same sites. The strongly depleted $\delta^{13} \mathrm{C}$ measurements of Siboglinum spp. meant that ellipse theta was skewed more towards horizontal (closer to zero) for nonhydrothermal sites.

\section{Discussion}

\subsection{Microbial signatures of hydrothermal activity}

Fatty acid profiles at the non-hydrothermal off-axis and Three Sisters sites indicated similar bacterial biomass. Bacterial biomass varied much more widely at Hook Ridge (Table 4). The Hook Ridge 2 sample is not directly comparable since it was sampled from sediment $0-2 \mathrm{~cm}$ b.s.f. (rather than $0-1 \mathrm{~cm}$ b.s.f. owing to sample mass availability). Organic carbon content, hydrogen sulfide flux, and taxonomic diversity were all lower at this site and may support the suggestion of a lower overall bacterial biomass (Aquilina et al., 2013; Bell et al., 2016b). The very high bacterial biomass at Hook Ridge 1 suggests a potentially very active bacterial community comparable to other hydrothermal sediments (Yamanaka and Sakata, 2004), but $\delta^{13} \mathrm{C}_{\text {org }}$ was qualitatively similar to non-hydrothermal sites, implying that chemosynthetic activity was not the dominant source of organic carbon or that the isotopic signatures of the basal carbon source (e.g. DIC) and the fractionation associated with FA synthesis resulted in similar $\delta{ }^{13} \mathrm{C}$ signatures.

A small number of the more abundant fatty acids had notable differences in relative abundance between hydrothermal and background sites (Table 4). For example, 16:1 $\omega 7$ has been linked to sulfur-cycling pathways (Colaço et al., 2007) and comprised $14.0-15.2 \%$ of abundance at nonhydrothermal sites and $20.0-23.5 \%$ at hydrothermal sites. However, 18:1 $\omega 7$, also a suggested PLFA linked to thiooxidation (McCaffrey et al., 1989; Colaço et al., 2007) occurred in lower abundance at hydrothermal sites (4.8 $11.1 \%)$ than non-hydrothermal sites (15.9-16.9\%) and was also abundant in deeper areas of the Antarctic shelf (Würzberg et al., 2011). Heavier carbon isotopic signatures $(>-15 \%)$ are generally associated with rTCA cycle carbon fixation (Hayes, 2001; Hugler and Sievert, 2011; Reid et al., 2013), suggesting that this pathway may have been active at the hydrothermal sites, albeit at probably quite low rates. Conversely, many of the lightest $\delta^{13} \mathrm{C}$ signatures (e.g. 19:1 $\omega 8,-56.6 \%$ o, off-axis site) were associated with the non-hydrothermal sites, although it should be noted that 19:1 $\omega 8$ has not been definitively linked to a particular bacterial process (Koranda et al., 2013; Dong et al., 2015). Lower FA carbon isotope signatures with small ranges (e.g. 

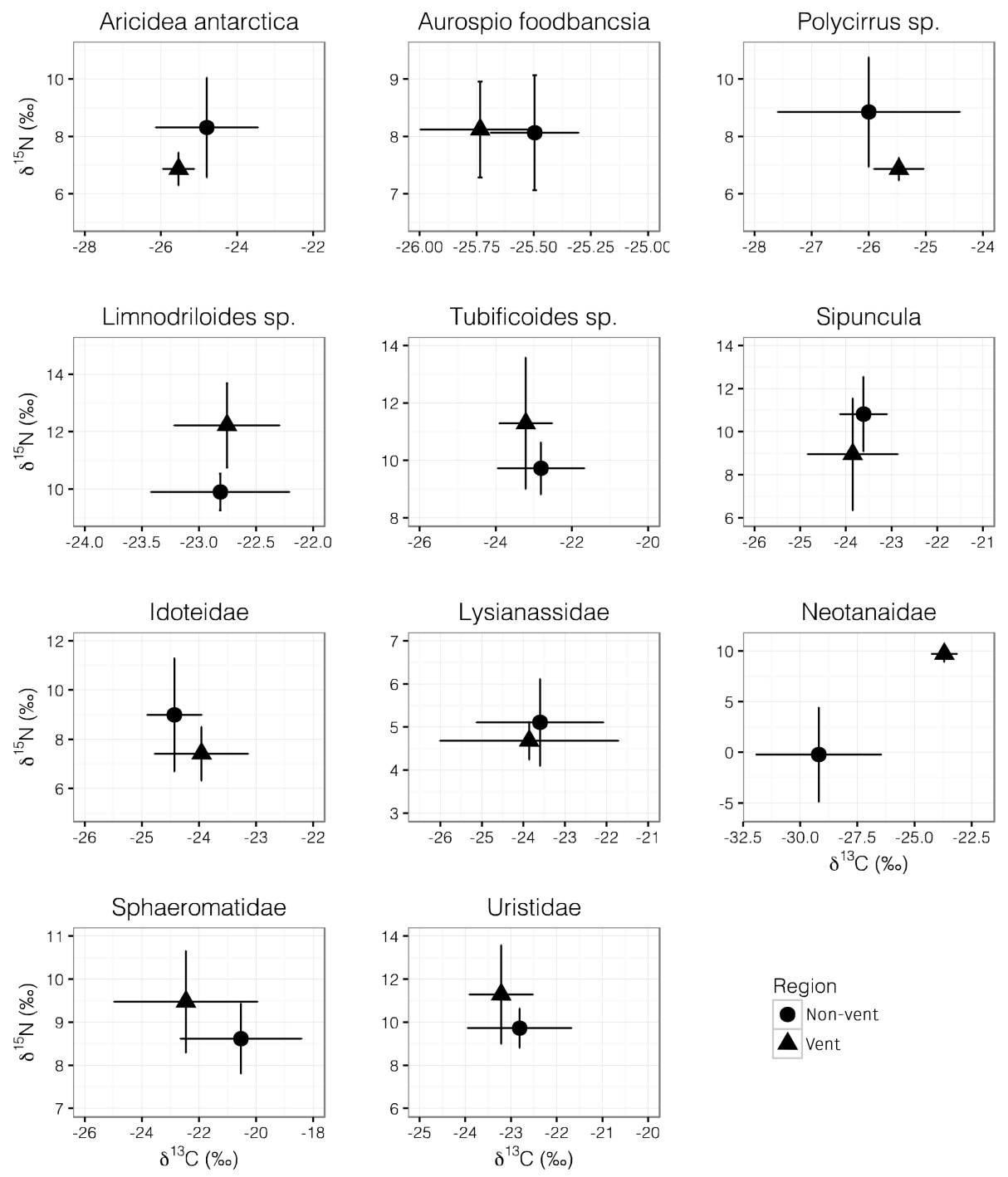

Figure 5. Biplot of $\mathrm{CN}$ isotopic data from species sampled at both hydrothermal sites and non-hydrothermal background regions. Mean \pm standard deviation, $X-Y$ scales vary.

-60 to $-50 \%$ o) could also be indicative of methane cycling, but most FAs at all sites had $\delta^{13} \mathrm{C}$ of $>-40 \%$. These results further suggest that chemosynthetic activity was relatively limited and support a rejection of hypothesis one; although there were differences between sites in PLFAs that are potentially indicative of chemosynthetic activity, these were not necessarily consistent between different PLFAs. The metabolic provenance of several of the more abundant PLFAs is also still uncertain. A number of fatty acids have been linked, though not exclusively, to chemoautotrophy, such as 10-Me-16:0 (Desulfobacter or Desulfocurvus, sulfate reducers) and 18:1 107 (Yamanaka and Sakata, 2004; Colaço et al., 2007; Klouche et al., 2009; Boschker et al., 2014), and their presence may be consistent with the hydrothermal signature of the sediment microbial community. There were notable proportions of compounds nor- mally associated with sulfate-reducing bacteria (Kohring et al., 1994; Boschker et al., 2014). These included iC15:0, aiC15:0, 1C17:0, and aiC17:0, which together constituted $\sim 8-12 \%$ of the FA suite. In addition, C16:1 $\omega 5 \mathrm{c}$ was relatively abundant (Fig. S1), and minor amounts of $10 \mathrm{MeC16}: 0$, C17:1 $\omega 8 \mathrm{c}$, and cycloC17:0 were present. These have also been used as indicators of sulfate-reducing bacteria and sometimes of particular groups (e.g. Guezennec and FialaMedioni, 1996; Boschker et al., 2014). These compounds indicate the presence of sulfate-reducing bacteria, although perhaps not as the dominant group. Although the FA suite was indicative of active sulfur-cycling activity, it remains difficult to be conclusive about the origin of most FAs, even those which have been regularly observed in chemosynthetic contexts (e.g. 18:1 $\omega 7$ ) and may still be abundant elsewhere (Würzberg et al., 2011). 


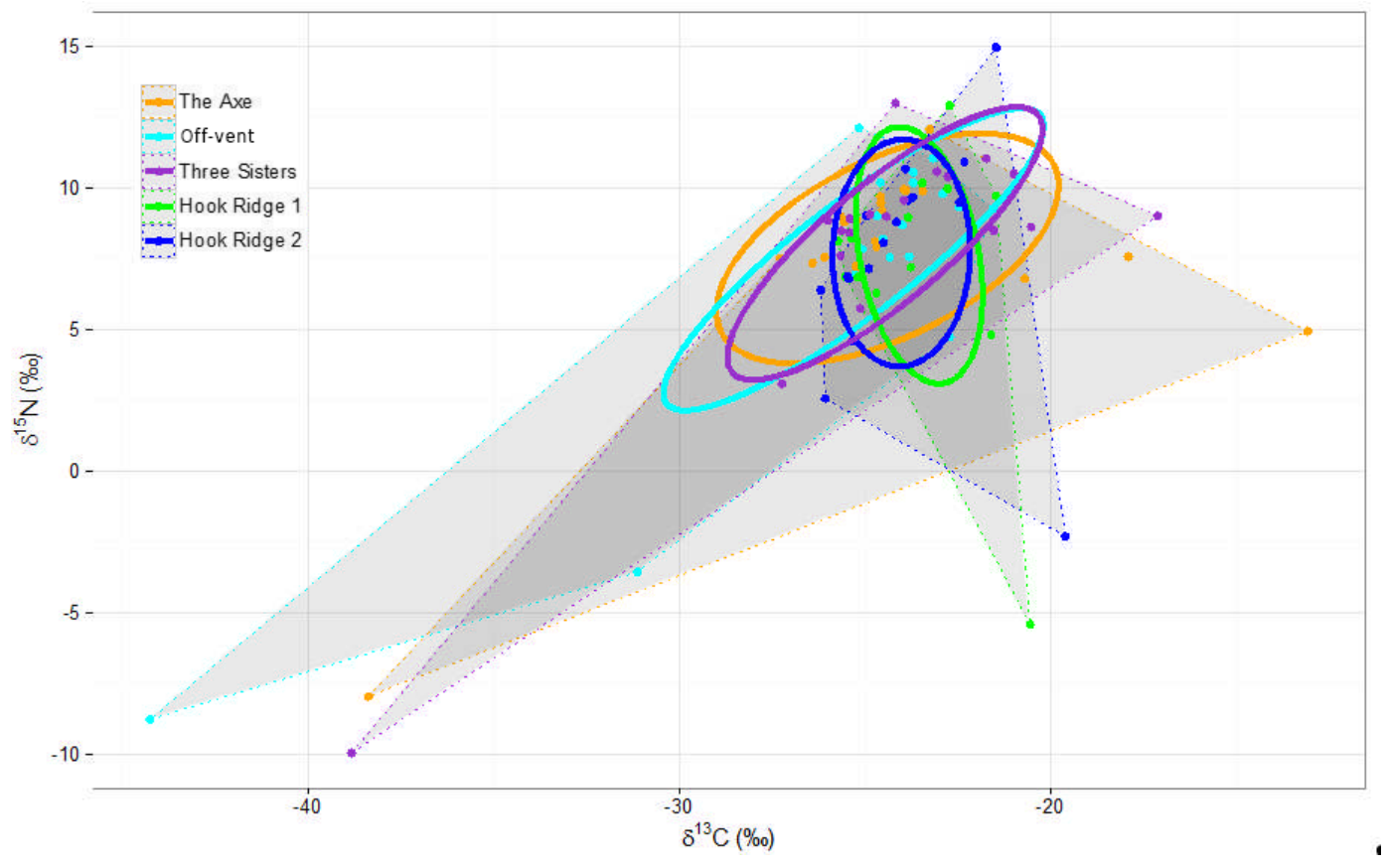

Figure 6. Faunal isotopic signatures (mean per species) grouped by site with total area (shaded area marked by dotted lines) and samplesize-corrected standard elliptical area (solid lines).

Together, C16:1 $\omega 7 \mathrm{c}$ and $\mathrm{C} 18: 1 \omega 7$ accounted for $\sim 25-$ $35 \%$ of the total FA suite and although they can be more generally associated with gram-negative eubacteria, they have frequently been linked to sulfur-oxidising bacteria in sediment samples (Pond et al., 1998; Yamanaka and Sakata, 2004; Boschker et al., 2014). Their dominance of the suite in the Bransfield Strait is similar to sediments from a vent in the Barbados Trench where C16:1 $\omega 7$ and C18:1 $\omega 7$ together contributed up to $50 \%$ of FAs (Guezennec and Fiala-Medioni, 1996).

Long chain fatty acids $(>\mathrm{C} 22)$ indicative of land plants (e.g. Yamanaka and Sakata, 2004) and typical indicators of marine phytoplankton production (e.g. C20:3 $\omega 5$ and $\mathrm{C} 22: 6 \omega 3)$ were very minor constituents, never accounting for more than $3 \%$ of total PLFA mass and only detected at the non-hydrothermal sites: off-vent and Middle Sister. While their low abundance is at least partially accounted for by rapid degradation during sinking through the water column (Veuger et al., 2012), it also suggests that sedimentary FAs were predominantly of bacterial origin, whether due to bacterial reworking of photosynthetic organic matter or in situ production.

Chemotrophic bacterial sequences, such as Blastopirellula (Schlesner, 2015), and Rhodopirellula (Bondoso et al., 2014), were found at all sites in relatively high abundance, suggesting widespread and active chemosynthesis, though the lack of a particularly dominant bacterial group associated with chemosynthetic activity suggested that the supply of chemosynthetic OM was likely relatively limited. It re- mains difficult, however, to determine which FAs these bacterial lineages may be have been synthesising.

Some FAs also had marked differences in $\delta^{13} \mathrm{C}$ signatures, even where there was strong compositional similarity between sites (i.e. the non-hydrothermal sites). This suggested that either there were differences in the isotopic values of inorganic or organic matter sources or different bacterial metabolic pathways were active. Between the non-hydrothermal sites, these included PUFAs and MUFAs (polyunsaturated and monounsaturated fatty acids) such as

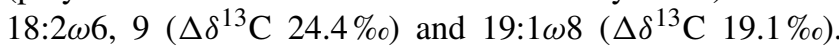
Differences in PLFA $\delta^{13} \mathrm{C}$ between the hydrothermal sites also ranged widely, with the largest differences associated with PLFAs such as 16:1 $\omega 11 \mathrm{t}\left(\Delta \delta^{13} \mathrm{C} 17.2 \%\right.$ ) and 10-Me16:0 $\left(\Delta \delta^{13} \mathrm{C} 11.0 \%\right.$ ). However, it should be stressed that all PLFAs with larger $\delta^{13} \mathrm{C}$ differences between sites were comparatively rare and never individually exceeded $5 \%$ of total abundance. Microbial signatures, whilst supporting the suggestion of chemosynthetic activity, are not indicative of chemosynthetic OM being the dominant source of organic matter to food webs at any site (hypothesis one). It is not possible to assess from PLFA data the relative importance of chemoautotrophic and photosynthetic OM sources, since PLFAs degrade quickly and therefore surface FA abundances are inevitably underestimated in deep water samples. 
Table 6. Ellipse area and Layman metrics of benthos by site. SEAc: sample-size-corrected standard elliptical area; SEA.B: Bayesian estimate of standard elliptical area; TA: total hull area; E: eccentricity; dNr: nitrogen range; dCr: carbon range; dSr: sulfur range; CD: centroid distance.

\begin{tabular}{|c|c|c|c|c|c|c|c|c|c|}
\hline \multirow[b]{2}{*}{ Site } & \multicolumn{4}{|c|}{ Ellipse } & \multirow[b]{2}{*}{$\Theta$} & \multirow[b]{2}{*}{$\mathrm{E}$} & \multirow[b]{2}{*}{$\mathrm{CD}$} & \multicolumn{2}{|c|}{$\begin{array}{l}\text { Nearest } \\
\text { neighbour } \\
\text { distance }\end{array}$} \\
\hline & $\begin{array}{l}\text { SEAc } \\
\left(\% o^{2}\right)\end{array}$ & $\begin{array}{r}\text { SEA.B } \\
\left(\% o^{2}\right)\end{array}$ & $\begin{array}{r}\text { Cred. } \\
\left(95 \% \pm \% o^{2}\right)\end{array}$ & $\begin{array}{r}\text { TA } \\
\left(\% o^{2}\right)\end{array}$ & & & & Mean & SD \\
\hline The Axe & 49.3 & 45.0 & 19.9 & 161.6 & 0.67 & 0.85 & 3.59 & 1.76 & 4.17 \\
\hline Off-vent & 39.8 & 36.5 & 16.8 & 139.1 & 0.81 & 0.97 & 4.34 & 2.13 & 3.88 \\
\hline Three Sisters & 35.5 & 32.6 & 14.7 & 110.2 & 0.86 & 0.95 & 3.85 & 1.93 & 3.78 \\
\hline Hook Ridge 1 & 23.1 & 20.7 & 11.2 & 42.6 & -1.43 & 0.94 & 3.30 & 1.64 & 2.60 \\
\hline Hook Ridge 2 & 23.4 & 21.1 & 10.7 & 61.8 & 1.55 & 0.89 & 3.17 & 1.52 & 2.03 \\
\hline \multicolumn{10}{|l|}{ Mean } \\
\hline Non-hydrothermal & 41.5 & 38.0 & 17.2 & 137.0 & 0.78 & 0.92 & 3.93 & 1.94 & 3.94 \\
\hline Hydrothermally active & 23.2 & 20.9 & 11.0 & 52.2 & 0.10 & 0.91 & 3.23 & 1.58 & 2.31 \\
\hline
\end{tabular}

\begin{tabular}{lrrrrr}
\hline & \multicolumn{4}{c}{ Centroid } & \\
\cline { 2 - 4 } Site & $\delta^{13} \mathrm{C}(\% \circ)$ & $\delta^{15} \mathrm{~N}(\% \circ)$ & $\delta^{34} \mathrm{~S}(\% \circ)$ & $\mathrm{dNr}(\% \circ)$ & $\mathrm{dCr}(\%)$ \\
\hline The Axe & -24.4 & 7.9 & & 20.0 & 25.3 \\
Off-vent & -25.3 & 7.5 & 8.1 & 20.9 & 22.7 \\
Three Sisters & -24.5 & 8.0 & & 22.9 & 21.7 \\
Hook Ridge 1 & -23.5 & 7.6 & 5.4 & 18.3 & 5.2 \\
Hook Ridge 2 & -24.0 & 7.7 & & 17.3 & 6.6 \\
\hline Mean & & & & 21.3 & 23.2 \\
Non-hydrothermally active & -24.7 & 7.8 & & 17.8 & 5.9 \\
\hline Hydrothermally active & -23.8 & 7.7 & & & \\
\hline
\end{tabular}

Note: dSR reported only for Hook Ridge 1 and the off-vent site since $\delta^{34} \mathrm{~S}$ values of siboglinids were only measured from these sites; hence dSr at other sites would be a considerable underestimate. As $\delta^{34} \mathrm{~S}$ values were comparatively under-representative, these values were not used in the calculation of any other metric. Data rounded to $1 \mathrm{dp}$.

\subsection{Siboglinids}

Both species of infaunal siboglinid (Sclerolinum contortum from Hook Ridge and the Siboglinum sp. from the nonhydrothermal sites) appeared to subsist upon chemosynthetically derived organic matter, as evidenced by their morphology and also by their strongly ${ }^{15} \mathrm{~N}$-depleted isotopic signatures (see values with $\delta^{15} \mathrm{~N}$ of $<-2 \%$ in Fig. 3). Low $\delta^{15} \mathrm{~N}$ signatures have also been observed in other siboglinids in a range of hydrothermal settings, such as Riftia pachyptila at the East Pacific Rise hard substratum vents (Rau, 1981). Diazotrophy has been detected previously in hydrothermal vents and cold seeps, typified by low $\delta^{15} \mathrm{~N}$ values (e.g. Rau, 1981; Desai et al., 2013; Wu et al., 2014; Yamanaka et al., 2015). Diazotrophy in various reducing settings has been found associated with the anaerobic oxidation of methane (Dekas et al., 2009), methanotrophy (Mehta and Baross, 2006), and (in a non-marine cave) sulfate reduction (Desai et al., 2013). The latter is also consistent with the low $\delta^{34} \mathrm{~S}$ signatures of both siboglinid species (Fig. 4), but gene expression analysis and/or isotopic tracing would be required to confirm this suggestion. Alternately, low $\delta^{15} \mathrm{~N}$ signatures may be explained by the uptake of ammonium produced through dissimilatory nitrate reduction (Naraoka et al., 2008; Liao et al., 2014; Bennett et al., 2015) or strong isotopic fractionation during utilisation of ammonia (Naraoka et al., 2008; Liao et al., 2014; Bennett et al., 2015). Bulk faunal isotopic signatures are inadequate to determine which of these chemosynthesisrelated mechanisms is responsible for Siboglinum $\delta^{15} \mathrm{~N}$ values, which would require analysis of the functional genes in the Siboglinum endosymbionts.

The $\delta^{15} \mathrm{~N}$ values for both siboglinids $\left(\delta^{15} \mathrm{~N}\right.$ Sclerolinum $-5.3 \%$ \pm 1.0 , Siboglinum $-8.9 \% \pm 0.8$ ) indicated reliance upon locally fixed $\mathrm{N}_{2}$ (Rau, 1981; Dekas et al., 2009, 2014; Wu et al., 2014; Yamanaka et al., 2015) rather than utilisation of sediment organic nitrogen $\left(\delta^{15} \mathrm{~N}=5.7 \% \circ \pm 0.7\right)$. These values were also in contrast to the rest of the nonchemosynthetic obligate species, which generally had much heavier $\delta^{15} \mathrm{~N}$ values. This supports hypothesis two that the siboglinid species were subsisting upon chemosynthetic OM, most likely supplied by their endosymbionts.

Carbon isotopic signatures in chemosynthetic primary production depend upon the mode of fixation and the initial ${ }^{13} \mathrm{C}$ of the inorganic substrate. Sclerolinum contortum $\delta^{13} \mathrm{C}$ 
$\left(-20.5 \% \circ \pm 1.0 \%\right.$ ) was depleted in $\delta^{13} \mathrm{C}$ relative to Southern Ocean DIC by around 10\%o (Henley et al., 2012; Young et al., 2013), giving it a signal within the fractionation range of the reverse tricarboxylic acid cycle (Yorisue et al., 2012), but the concentration and isotopic composition of DIC can undergo considerable alteration in hydrothermal sediments (Walker et al., 2008). Therefore, without measurements of $\delta^{13} \mathrm{C}$ in pore fluid DIC, it was not possible to determine which fixation pathway(s) were being used by $S$. contortum endosymbionts.

Sulfur isotopic signatures in $S$. contortum were very low and quite variable $(-26.7 \%$ o $\pm 3.5 \%$ ). Sclerolinum endosymbionts may have been utilising sulfide either from hydrothermal fluid, microbial sulfate reduction, or redissolved from hydrothermal precipitates. Mineral sulfide was present at Hook Ridge that ranged between -28.1 and $+5.1 \%$ (Petersen et al., 2004), which is consistent with the relatively high $\delta^{34} S$ variability in $S$. contortum. Alternatively, sulfide supplied as a result of microbial sulfate reduction (Canfield, 2001) may have been the primary source of organic sulfur, similar to that of solemyid bivalves in reducing sediments (mean $\delta^{34} \mathrm{~S}$ of -30 to $-20 \%$; Vetter and Fry (1998) and in cold seep settings (Yamanaka et al., 2015). Sulfate reduction can also be associated with the anaerobic oxidation of methane (Whiticar and Suess, 1990; Canfield, 2001; Dowell et al., 2016), suggesting that methanotrophic pathways could also have been important at Hook Ridge. (e.g. abundance of Methylohalomonas, $2.1-4.3 \%$ of sequences at all sites; Table 3). Although endosymbiont composition data were not available for the Southern Ocean population, Sclerolinum contortum is also known from hydrocarbon seeps in the Gulf of Mexico (Eichinger et al., 2013; Eichinger et al., 2014; Georgieva et al., 2015) and the Håkon Mosby mud volcano in the Arctic Ocean where $S$. contortum $\delta^{13} \mathrm{C}$ ranged between -48.3 and $-34.9 \%$ (Gebruk et al., 2003), demonstrating that this species can occupy several reducing environments and use a range of chemosynthetic fixation pathways, including sulfide oxidation and methanotrophy (Eichinger et al., 2014; Georgieva et al., 2015).

The Siboglinum sp. $\delta^{13} \mathrm{C}$ values (mean -41.4 , range -45.7 to $-38.1 \%, n=8$ ) corresponded very closely to published values of thermogenic methane ( -43 to $-38 \%$ ) from the Bransfield Strait (Whiticar and Suess, 1990), strongly suggesting that methanotrophy was the dominant carbon source for this species. Biogenic methane, although present in the Bransfield Strait, typically has much lower $\delta^{13} \mathrm{C}$ values (Whiticar, 1999; Yamanaka et al., 2015), indicating a hydrothermal and/or thermogenic source of methane in the Bransfield Strait (Whiticar and Suess, 1990). Sulfur isotopic signatures were also very low in the Siboglinum sp.: $\delta^{34} \mathrm{~S}$ $-22.9 \%$ in one sample from 15 pooled individuals from the off-axis site, the lowest measurement of $\delta^{34} \mathrm{~S}$ reported for this genus (Schmaljohann and Flügel, 1987; Rodrigues et al., 2013). Methanotrophy in Siboglinum spp. has been previously documented at seeps in the NE Pacific (Bernardino and Smith, 2010), the Norwegian margin $\left(\delta^{13} \mathrm{C}-78.3\right.$ to $-62.2 \%$ ) (Schmaljohann et al., 1990), and Atlantic mud volcanoes $\left(\delta^{13} \mathrm{C}\right.$ range -49.8 to $-33.0 \%$; Rodrigues et al., 2013). Rodrigues et al. (2013) also reported a greater range in $\delta^{15} \mathrm{~N}$ than observed in the Bransfield siboglinids $\left(\delta^{15} \mathrm{~N}-1.3\right.$ to $12.2 \%$ and -10.2 to $-7.6 \%$, respectively). This suggests that in comparison to Siboglinum spp. in Atlantic mud volcanoes, which seemed to be using a mixture of organic matter sources (Rodrigues et al., 2013), the Bransfield specimens relied much more heavily upon a single OM source, suggesting considerable trophic plasticity in this genus worldwide.

Off-vent methanotrophy using thermogenic methane potentially illustrates an indirect dependence upon hydrothermalism (Whiticar and Suess, 1990). Sediment methane production is thought to be accelerated by the heat flux associated with the mixing of hydrothermal fluid in sediment (Whiticar and Suess, 1990), and sediment and Siboglinum isotopic data suggest that the footprint of hydrothermal influence may be much larger than previously recognised, giving rise to transitional environments (Bell et al., 2016a; Levin et al., 2016). A clear contribution of methane-derived carbon to consumer diets was limited predominately to neotanaids, which is consistent with the relatively small population sizes (64-159 ind. $\left.\mathrm{m}^{2}\right)$ of the Siboglinum sp. observed in the Bransfield Strait (Bell et al., 2016b).

\subsection{Organic matter sources}

Pelagic salps, collected from an Agassiz trawl at Hook Ridge $(1647 \mathrm{~m})$, were presumed to most closely represent a diet of entirely surface-derived material and were more depleted in ${ }^{13} \mathrm{C}$ and more enriched in ${ }^{34} \mathrm{~S}$ than were sediments (salp $\delta^{13} \mathrm{C}-27.4 \%$ and $\delta^{34} \mathrm{~S} 20.1$; Hook Ridge sediment $\delta^{13} \mathrm{C}-26.2 \%$ and $\left.\delta^{34} \mathrm{~S} 14.3\right)$. Salp carbon isotopic signatures were also lighter than the majority of macrofauna or sedimentary organic carbon, both at Hook Ridge and the nonhydrothermal sites (Fig. 3), and similar to other suspensionfeeding fauna in the Bransfield Strait (Elias-Piera et al., 2013).

Fauna with more depleted $\delta^{34} \mathrm{~S}$ and/or more enriched $\delta^{13} \mathrm{C}$ values were likely to have derived at least a small amount of their diet from chemosynthetic sources (potentially indirectly through the non-selective consumption of detrital OM) both at hydrothermal and background regions (Bell et al., 2017a). Carbon and sulfur isotopic measurements indicated mixed sources for most consumers between chemosynthetic OM and surface-derived photosynthetic OM. The low content of algal biomarkers (particularly at the hydrothermal sites) suggests that phytodetritus was probably quite degraded and thus challenging to detect using short-lived fatty acids. However, the Bransfield Strait can be subject to substantial export production and it is probable that surface production contributes much more to sea floor OM than is evident from the fatty acid composition. Non-hydrothermal sediments were more enriched in ${ }^{34} \mathrm{~S}$ than hydrothermal sediments, an offset that 
probably resulted from greater availability of lighter sulfur sources such as sulfide oxidation at Hook Ridge, even if surface-derived OM remained the dominant source of organic matter at the hydrothermal sites (Bell et al., 2017a).

Samples of bacterial mat could not be collected during JC55 (Tyler et al., 2011) and without these end-member measurements, it was not possible to quantitatively model resource partitioning in the Bransfield Strait using isotope mixing models (Phillips et al., 2014). Bacterial mats from hightemperature vents in the Southern Ocean had $\delta^{34} \mathrm{~S}$ values of $0.8 \%$ (Reid et al., 2013), and at sedimented areas of the Loki's Castle hydrothermal vents in the Arctic Ocean they have $\delta^{34} \mathrm{~S}$ values of $-4.9 \%$ (bulk sediment; Jaeschke et al., 2014). Therefore it is probable that low faunal $\delta^{34} \mathrm{~S}$ values represent a contribution of chemosynthetic OM (from either siboglinid tissue or free-living bacteria). Inorganic sulfur can also be a source to consumers when sulfide is utilised by free-living bacteria $\left(\delta^{34} \mathrm{~S}\right.$ ranged from -7.3 to $5.4 \%$; Erickson et al., 2009) and although we could not analyse the $\delta^{34} \mathrm{~S}$ of fluid sulfide, sulfide crusts have been found at Hook Ridge and may provide a proxy for typical isotopic composition $\left(\delta^{34} \mathrm{~S}-28.1\right.$ to $5.1 \%$; Petersen et al., 2004). There were several species (e.g. tubificid oligochaetes) that had moderately depleted $\delta^{34} \mathrm{~S}$ signatures, such as Limnodriloides spp. $\left(\delta^{34} \mathrm{~S} 7.6 \%\right.$ at hydrothermal sites, $-1.2 \%$ at nonhydrothermal sites; Fig. 4), further supporting the hypothesis of different trophic positions between hydrothermal and nonhydrothermal regions (hypothesis two). This provides evidence of the coupled anaerobic oxidation of methane-sulfate reduction, but overall the contribution of $\delta^{34} \mathrm{~S}$-depleted bacterial production did not seem widespread (further rejecting hypothesis four).

Without samples of all OM sources we cannot quantitatively assert that the faunal utilisation of chemosynthetic OM was low in the Bransfield Strait. Although isotopic data were consistent with several OM sources, it seemed unlikely that chemosynthetic OM was a dominant source of OM to the vast majority of taxa. The apparently limited consumption of chemosynthetic OM suggested that either it was not widely available (e.g. patchy or low density of endosymbiont-bearing fauna; Bell et al., 2016b) or that the ecological stress associated with feeding in areas of in situ production was a significant deterrent to many species (Bernardino et al., 2012; Levin et al., 2013).

\subsection{A priori vs. a posteriori trophic groups}

Classifications based upon morphology did not prove to be an accurate predictor of isotopic data, suggesting that faunal behaviour is potentially more important in determining dietary composition than morphology (e.g. having or lacking jaws). Peracarid species that possessed structures adapted to a motile, carnivorous lifestyle were assigned to a carnivore or scavenger guild (Bell et al., 2016b) and were distributed throughout the food web both at hydrothermal sites and background regions, indicating more diverse feeding strategies than expected. Taxa presumed to be deposit feeders (largely annelids) also had a large range of $\delta^{15} \mathrm{~N}$ values. This may reflect the consumption of detritus from both "fresh" and more recycled or refractory OM sources as observed in other non-hydrothermal sedimented deep-sea habitats (Iken et al., 2001; Reid et al., 2012) or reflect variability in trophic discrimination related to diet quality (Adams and Sterner, 2000). A range of foraminifera have now been shown to utilise denitrification, which results in their having heavier $\delta^{15} \mathrm{~N}$ values (Pina-Ochoa et al., 2010; Jeffreys et al., 2015). The result is high $\delta^{15} \mathrm{~N}$ values in taxa without predatory morphology (e.g. oligochaetes). Tubificid oligochaetes had higher $\delta^{15} \mathrm{~N}$ values at the hydrothermal sites, suggesting that they fed upon more recycled organic matter, possibly owing to greater microbial activity at hydrothermal sites.

Several taxa (e.g. ophiuroids at Hook Ridge) had low $\delta^{15} \mathrm{~N}$ values relative to sediment $\mathrm{OM}$, suggesting preferential consumption of chemosynthetic OM (Rau, 1981; Dekas et al., 2014). In these taxa, it is likely that the widespread but patchy bacterial mats or Sclerolinum populations at Hook Ridge (Aquilina et al., 2013) were an important source of organic matter. Fauna from the non-hydrothermal sites with low $\delta^{15} \mathrm{~N}$ (e.g. neotanaids) were likely subsisting in part upon siboglinid tissue (Siboglinum spp.). There were no video transects over the off-axis site but footage of the Three Sisters, which was similar in macrofaunal composition (Bell et al., 2016b), did not reveal bacterial mats (Aquilina et al., 2013), and hence it is unlikely that these were an important resource at non-hydrothermal sites.

It is clear that some fauna can exhibit a degree of trophic plasticity depending upon habitat (supporting hypothesis four). This is consistent with other hydrothermal sediments in which several taxa (e.g. the Prionospio sp. Polychaeta: Spionidae) had different isotopic signatures depending upon their environment (Levin et al., 2009), demonstrating differential patterns in resource utilisation. Alternatively, there could have been different $\delta^{15} \mathrm{~N}$ baselines between sites, though if these differences were significant, we argue that it is likely that more species would have had significant differences in tissue $\delta^{15} \mathrm{~N}$. Conversely, samples of Aurospio foodbancsia at both hydrothermal and non-hydrothermal sites had broadly similar $\delta^{15} \mathrm{~N}$ values to those of the west Antarctic Peninsula (8 and $7.9 \%$, respectively), albeit with higher variability (Mincks et al., 2008). The $\delta^{13} \mathrm{C}$ values of Aurospio were also broadly similar, implying that this species occupied a detritivorous trophic niche regardless of environmental conditions.

\subsection{Impact of hydrothermal activity on community trophodynamics}

Standard ellipse area was lower at Hook Ridge than elsewhere (Table 6), which is analogous to trends in macrofaunal diversity and abundance in the Bransfield Strait (Bell 
et al., 2016b) and changes in SEA.B along a gradient of methane flux at vent and seep ecosystems in the Guaymas Basin (Portail et al., 2016). This demonstrates that at community level, ellipse area can be associated with other macrofaunal assemblage characteristics. A concurrent decline in niche area and alpha diversity is consistent with the concept that species have finely partitioned niches, and greater total niche area permits higher biodiversity (McClain and Schlacher, 2015). This relationship may also suggest that the influence of disturbance gradients created by hydrothermalism can result in an impoverished community (McClain and Schlacher, 2015; Bell et al., 2016b). Productivity-diversity relationships in which higher productivity sustains higher diversity have also been suggested for deep-sea ecosystems (McClain and Schlacher, 2015; Woolley et al., 2016), but this is not supported by the Bransfield Strait sites (Bell et al., 2017a). We suggest that in the Bransfield Strait the environmental toxicity in hydrothermal sediments (from differences in temperature and porewater chemistry) causes a concomitant decline in both trophic and species diversity (Bell et al., 2016b) in spite of the potential for increased localised production (Bell et al., 2017a). However, we acknowledge that, owing to the high small-scale habitat heterogeneity apparent from video imagery over the hydrothermally influenced area, it is likely that the contribution of chemosynthetic organic matter varies widely over tens of metres at Hook Ridge.

Community-based trophic metrics (Layman et al., 2007) indicated that, although measures of dispersion within sites were relatively similar between hydrothermal sites and background areas (Table 6), trophic diversity, particularly in terms of the range of carbon sources ( $\mathrm{dCr}$ ) and total hull area (TA), were higher at background sites due to the more depleted carbon and nitrogen signatures of Siboglinum spp. It is still unclear whether the assemblage isotopic niche really corresponds to its actualised trophic niche, and although the niche space was smaller at the hydrothermal sites, the potential for different trophic strategies was still potentially greater (Bell et al., 2017a).

\section{Conclusions}

In this study, we demonstrate the influence of sedimenthosted hydrothermal activity upon trophodynamics and microbial populations. Low-activity hydrothermal microbiota were more similar to the non-hydrothermal site than to highactivity populations, illustrating the effect of ecological gradients upon deep-sea microbial diversity. Despite widespread bacterial mats and populations of vent-endemic macrofauna, the utilisation of chemosynthetic OM amongst non-specialist macrofauna and megafauna seemed relatively low, with a concomitant decline in trophic diversity with increasing hydrothermal activity. Morphology was also not indicative of trophic relationships, demonstrating the effects of differential resource availability and behaviour. We suggest that, be- cause these sedimented hydrothermal sites are insufficiently active to host large populations of vent-endemic megafauna, the transfer of chemosynthetic organic matter into the metazoan food web is likely to be more limited than in other similar environments.

\section{Ethics statement}

In accordance with the Antarctic Act (1994) and the Antarctic Regulations (1995), necessary permits (S5-4/2010) were acquired from the South Georgia and South Sandwich Islands Government.

Data availability. The data published here can be found at https: //doi.org/10.5518/301 (Bell et al., 2017b).

\section{The Supplement related to this article is available online at https://doi.org/10.5194/bg-14-5705-2017-supplement.}

Author contributions. Conceived and designed the sampling programme: WDKR, DAP, AGG, CJS, and CW. Sample laboratory preparation and isotopic analyses: JBB, JN, and CJS. Microbial sequencing: DAP. Statistical analyses: JBB. Produced figures: JBB. Wrote the paper: JBB, CW, and WDKR, with contributions and comments from all other authors.

Competing interests. The authors declare that they have no conflict of interest.

Acknowledgements. James B. Bell was funded by a NERC PhD Studentship (NE/L501542/1). This work was funded by the NERC ChEsSo consortium (Chemosynthetically driven Ecosystems South of the Polar Front; NERC grant NE/DOI249X/I). Elemental analyses were funded by the NERC Life Sciences Mass Spectrometry Facility (proposal no. EK234-13/14). We thank Barry Thornton and the James Hutton Laboratory, Aberdeen for processing the PLFA samples. We also thank Will Goodall-Copestake for assistance in processing the $16 \mathrm{~S}$ sequence data. We are grateful to the Master and Crew of RRS James Cook cruise 055 for technical support and the Cruise Principal Scientific Officer, Professor Paul Tyler.

Edited by: Hiroshi Kitazato

Reviewed by: two anonymous referees

\section{References}

Adams, T. S. and Sterner, R. W.: The effect of dietary nitrogen content on trophic level ${ }^{15} \mathrm{~N}$ enrichment, Limnol. Oceanogr., 45, 601-607, 2000. 
Aquilina, A., Connelly, D. P., Copley, J. T., Green, D. R., Hawkes, J. A., Hepburn, L., Huvenne, V. A., Marsh, L., Mills, R. A., and Tyler, P. A.: Geochemical and Visual Indicators of Hydrothermal Fluid Flow through a Sediment-Hosted Volcanic Ridge in the Central Bransfield Basin (Antarctica), Plos One, 8, e54686, https://doi.org/10.1371/journal.pone.0054686, 2013.

Aquilina, A., Homoky, W. B., Hawkes, J. A., Lyons, T. W., and Mills, R. A.: Hydrothermal sediments are a source of water column Fe and $\mathrm{Mn}$ in the Bransfield Strait, Antarctica, Geochim. Cosmochim. Ac., 137, 64-80, 2014.

Bell, J. B., Aquilina, A., Woulds, C., Glover, A. G., Little, C. T. S., Reid, W. D. K., Hepburn, L. E., Newton, J., and Mills, R. A.: Geochemistry, faunal composition and trophic structure at an area of weak methane seepage on the southwest South Georgia margin, Roy. Soc. Open Sci., 3, 160284, https://doi.org/10.1098/rsos.160284, 2016a.

Bell, J. B., Woulds, C., Brown, L. E., Little, C. T. S., Sweeting, C. J., Reid, W. D. K., and Glover, A. G.: Macrofaunal ecology of sedimented hydrothermal vents in the Bransfield Strait, Antarctica, Front. Mar. Sci., 3, 32, 2016 b.

Bell, J. B., Woulds, C., and van Oevelen, D.: Hydrothermal activity, functional diversity and chemoautotrophy are major drivers of seafloor carbon cycling, Sci. Rep., 7, 12025, https://doi.org/10.1038/s41598-017-12291-w, 2017a.

Bell, J., Reid, W. D. K., Pearce, D. A., Glover, A. G., Sweeting, C. J., Newton, J., and Woulds, C.: Macrofaunal and sedimentary phospholipid fatty acid natural isotopic $(\mathrm{C}, \mathrm{N}, \mathrm{S})$ data from sites in the Bransfield Strait, Antarctica University of Leeds, https://doi.org/10.5518/301, 2017b.

Bemis, K., Lowell, R., and Farough, A.: Diffuse Flow On and Around Hydrothermal Vents at Mid-Ocean Ridges, Oceanography, 25, 182-191, 2012.

Bennett, S. A., Dover, C. V., Breier, J. A., and Coleman, M.: Effect of depth and vent fluid composition on the carbon sources at two neighboring deep-sea hydrothermal vent fields (Mid-Cayman Rise), Deep-Sea Res. Pt. I, 104, 122-133, 2015.

Bernardino, A. F., Levin, L. A., Thurber, A. R., and Smith, C. R.: Comparative Composition, Diversity and Trophic Ecology of Sediment Macrofauna at Vents, Seeps and Organic Falls, Plos ONE, 7, e33515, https://doi.org/10.1371/journal.pone.0033515, 2012.

Bernardino, A. F. and Smith, C. R.: Community structure of infaunal macrobenthos around vestimentiferan thickets at the San Clemente cold seep, NE Pacific, Mar. Ecol., 31, 608-621, 2010.

Bligh, E. G.: A rapid method of total lipid extration and purification, Can. J. Biochem. Phsiol., 37, 911-917, 1959.

Bondoso, J., Albuquerque, L., Lobo-da-Cunha, A., da Costa, M. S., Harder, J., and Lage, O. M.: Rhodopirellula lusitana sp. nov. and Rhodopirellula rubra sp. nov., isolated from the surface of macroalgae, Syst. Appl. Microbiol., 37, 157-164, 2014.

Boschker, H. T. and Middelburg, J. J.: Stable isotopes and biomarkers in microbial ecology, FEMS Microbiol. Ecol., 40, 85-95, 2002.

Boschker, H. T., Vasquez-Cardenas, D., Bolhuis, H., MoerdijkPoortvliet, T. W., and Moodley, L.: Chemoautotrophic carbon fixation rates and active bacterial communities in intertidal marine sediments, PLoS One, 9, e101443, https://doi.org/10.1371/journal.pone.0101443, 2014.
Canfield, D. E.: Isotope fractionation by natural populations of sulfate-reducing bacteria, Geochim. Cosmochim. Ac., 65, 11171124, 2001.

Clarke, K. R., Somerfield, P. J., and Gorley, R. N.: Testing of null hypotheses in exploratory community analyses: similarity profiles and biota-environment linkage, J. Exp. Mar. Biol. Ecol., 366, 56-69, 2008.

Colaço, A., Desbruyères, D., and Guezennec, J.: Polar lipid fatty acids as indicators of trophic associations in a deep-sea vent system community, Mar. Ecol., 28, 15-24, 2007.

Connolly, R. M. and Schlacher, T. A.: Sample acidification significantly alters stable isotope ratios of sulfur in aquatic plants and animals, Mar. Ecol. Prog. Ser., 493, 1-8, 2013.

Dählmann, A., Wallman, K., Sahling, H., Sarthou, G., Bohrmann, G., Petersen, S., Chin, C. S., and Klinkhammer, G. P.: Hot vents in an ice-cold ocean: Indications for phase separation at the southernmost area of hydrothermal activity, Bransfield Strait, Antarctica, Earth Planet. Sci. Lett., 193, 381-394, 2001.

Dekas, A. E., Chadwick, G. L., Bowles, M. W., Joye, S. B., and Orphan, V. J.: Spatial distribution of nitrogen fixation in methane seep sediment and the role of the ANME archaea, Environ. Microbiol., 16, 3012-3029, 2014.

Dekas, A. E., Poretsky, R. S., and Orphan, V. J.: Deep-sea archaea fix and share nitrogen in methane-consuming microbial consortia, Science, 326, 422-426, 2009.

Desai, M. S., Assig, K., and Dattagupta, S.: Nitrogen fixation in distinct microbial niches within a chemoautotrophy-driven cave ecosystem, Isme J., 7, 2411-2423, 2013.

Dong, L.-J., Sun, Z.-K., Gao, Y., and He, W.-M.: Two-year interactions between invasive Solidago canadensis and soil decrease its subsequent growth and competitive ability, J. Plant Ecol., 6, 617-622, 2015.

Dowell, F., Cardman, Z., Dasarathy, S., Kellerman, M., Lipp, J. S., Ruff, S. E., Biddle, J. F., McKay, L., MacGregor, B. J., Lloyd, K. G., Albert, D. B., Mendlovitz, H., Hinrichs, K. U., and Teske, A.: Microbial communities in methane- and short chain alkane-rich hydrothermal sediments of Guaymas Basin, Front. Microbiol., 7, 2016.

Eichinger, I., Hourdez, S., and Bright, M.: Morphology, microanatomy and sequence data of Sclerolinum contortum (Siboglindae, Annelida) of the Gulf of Mexico, Org. Divers. Evol., 13, 311-329, 2013.

Eichinger, I., Schmitz-Esser, S., Schmid, M., Fisher, C. R., and Bright, M.: Symbiont-driven sulfur crystal formation in a thiotrophic symbiosis from deep-sea hydrocarbon seeps, Environ. Microbiol. Rep., 6, 364-372, 2014.

Elias-Piera, F., Rossi, S., Gili, J. M., and Orejas, C.: Trophic ecology of seven Antarctic gorgonian species, Mar. Ecol. Prog. Ser., 477, 93-106, 2013.

Erickson, K. L., Macko, S. A., and Van Dover, C. L.: Evidence for a chemotrophically based food web at inactive hydrothermal vents (Manus Basin), Deep-Sea Res. Pt. II, 56, 1577-1585, 2009.

Fanelli, E., Cartes, J. E., Enric, J., Papiol, V., Rumolo, P., and Sprovieri, M.: Effects of preservation on the $\delta 13 \mathrm{C}$ and $\delta 15 \mathrm{~N}$ values of deep sea macrofauna, J. Exp. Mar. Biol. Ecol., 395, 93-97, 2010.

Fry, B., Jannasch, H. W., Molyneaux, S. J., Wirsen, C. O., Muramoto, J. A., and King, S.: Stable Isotope Studies of the Car- 
bon Nitrogen and Sulfur Cycles in the Black Sea and the Cariaco Trench, Deep-Sea Res. Pt. A, 38, S1003-S1020, 1991.

Gebruk, A., Krylova, E., Lein, A., Vinogradov, G., Anderson, E., Pimenov, N., Cherkashev, G., and Crane, K.: Methane seep community of the Håkon Mosby mud volcano (the Norwegian Sea): composition and trophic aspects, Sarsia, 88, 394-403, 2003.

Georgieva, M., Wiklund, H., Bell, J. B., Eilersten, M. H., Mills, R. A., Little, C. T. S., and Glover, A. G.: A chemosynthetic weed: the tubeworm Sclerolinum contortum is a bipolar, cosmopolitan species, BMC Evol. Biol., 15, 280, https://doi.org/10.1186/s12862-015-0559-y, 2015.

Gollner, S., Govenar, B., Fisher, C. R., and Bright, M.: Size matters at deep-sea hydrothermal vents: different diversity and habitat fidelity patterns of meio- and macrofauna, Mar. Ecol. Prog. Ser., 520, 57-66, 2015.

Guezennec, J. and Fiala-Medioni, A.: Bacterial abundance and diversity in the Barbados Trench determined by phospholipid analysis, Microbiol. Ecol., 19, 83-93, 1996.

Hayes, J. M.: Fractionation of carbon and hydrogen isotopes in biosynthetic processes, Rev. Mineral. Geochem., 43, 225-277, 2001.

Henley, S. F., Annett, A. L., Ganeshram, R. S., Carson, D. S., Weston, K., Crosta, X., Tait, A., Dougans, J., Fallick, A. E., and Clarke, A.: Factors influencing the stable carbon isotopic composition of suspended and sinking organic matter in the coastal Antarctic sea ice environment, Biogeosciences, 9, 1137-1157, https://doi.org/10.5194/bg-9-1137-2012, 2012

Hothorn, T., van de Wiel, M. A., and Zeilis, A.: Package "Coin": Conditional Inference Procedures in a Permutation Test Framework, cranr-projectorg, https://cran.r-project.org/web/packages/ coin/index.html, 2015.

Hugler, M. and Sievert, S. M.: Beyond the Calvin cycle: autotrophic carbon fixation in the ocean, Annu. Rev. Mar. Sci., 3, 261-289, 2011.

Iken, K., Brey, T., Wand, U., Voight, J., and Junghans, P.: Trophic relationships in the benthic community at Porcupine Abyssal Plain (NE Atlantic): a stable isotope analysis, Prog. Oceanogr., 50, 383-405, 2001.

Jackson, A. L., Inger, R., Parnell, A. C., and Bearhop, S.: Comparing isotopic niche widths among and within communities: SIBER - Stable Isotope Bayesian Ellipses in $R$, J. Anim. Ecol., 80, 595-602, 2011.

Jaeschke, A., Eickmann, B., Lang, S. Q., Bernasconi, S. M., Strauss, H., adn Fruh-Green, G. L.: Biosignatures in chimney structures and sediment from the Loki's Castle low-temperature hydrothermal vent field at the Arctic Mid-Ocean Ridge, Extremophiles, 18, 545-560, 2014.

Jeffreys, R. M., Fisher, E. H., Gooday, A. J., Larkin, K. E., Billett, D. S. M., and Wolff, G. A.: The trophic and metabolic pathways of foraminifera in the Arabian Sea: evidence from cellular stable isotopes, Biogeosciences, 12, 1781-1797, https://doi.org/10.5194/bg-12-1781-2015, 2015.

Kallmeyer, J. and Boetius, A.: Effects of Temperature and Pressure on Sulfate Reduction and Anaerobic Oxidation of Methane in Hydrothermal Sediments of Guaymas Basin, Appl. Environ. Microbiol., 70, 1231-1233, 2004.

Kearse, M., Moir, R., Wilson, A., Stones-Havas, S., Cheung, M., Sturrock, S., Buxton, S., Cooper, A., Markowitz, S., Duran, C., Thierer, T., Ashton, B., Mentjies, P., and Drummond, A.:
Geneious Basic: an integrated and extendable desktop software platform for the organization and analysis of sequence data, Bioinformatics, 28, 1647-1649, 2012.

Kharlamenko, V. I., Zhukova, N. V., Khotimchenko, S. V., Svetashev, V. I., and Kamenev, G. M.: Fatty-acids as markers of food sources in a shallow-water hydrothermal ecosystem (Kraternaya Bight, Yankich island, Kurile Islands), Mar. Ecol. Prog. Ser., 120, 231-241, 1995.

Kiel, S.: A biogeographic network reveals evolutionary links between deep-sea hydrothermal vent and methane seep faunas, P. Roy. Soc. B-Biol. Sci., 283 https://doi.org/10.1371/journal.pone.0101443, 2016.

Klinkhammer, G. P., Chin, C. S., Keller, R. A., Dahlmann, A., Sahling, H., Sarthou, G., Petersen, S., and Smith, F.: Discovery of new hydrothermal vent sites in Bransfield Strait, Antarctica, Earth Planet. Sc. Lett., 193, 395-407, 2001

Klouche, N., Basso, O., Lascourréges, J.-F., Cavol, J.-L., Thomas, P., Fauque, G., Fardeau, M.-L., and Magot, M.: Desulfocurvus vexinensis gen. nov., sp. nov., a sulfate-reducing bacterium isolated from a deep subsurface aquifer, Int. J. Syst. Evol. Micr., 30, 3100-3104, 2009.

Kohring, L., Ringelberg, D., Devereuk, R., Stahl, D. A., Mittelman, M. W., and White, D. C.: Comparison of phylogenetic relationships based on phospholipid fatty acid profiles and ribosomal RNA sequence similarities among dissimiltory sulfate-reducing bacteria, Fems Microbiol. Lett., 119, 303-308, 1994.

Koranda, M., Kaiser, C., Fuchslueger, L., Kitzler, B., Sessitsch, A., Zechmeister-Boltenstern, S., and Rickhter, A.: Fungal and bacterial utilization of organic substrates depends on substrate complexity and $\mathrm{N}$ availability, in: International Institute for Applied Systems Analysis, edited by: Dieckmann, U., Laxenburg, Austria, 2013.

Layman, C. A., Arrington. D. A., Montaña, C. G., and Post, D. M.: Can Stable Isotope Ratios Provide For Community-Wide Measures of Trophic Structure?, Ecology, 88, 42-48, 2007.

Levin, L. A., Baco, A. R., Bowden, D., Colaço, A., Cordes, E., Cunha, M. R., Demopoulos, A., Gobin, J., Grupe, B., Le, J., Metaxas, A., Netburn, A., Rouse, G. W., Thurber, A. R., Tunnicliffe, V., Van Dover, C., Vanreusel, A., and Watling, L.: Hydrothermal Vents and Methane Seeps: Rethinking the Sphere of Influence, Front. Mar. Sci., 3, 72, https://doi.org/10.3389/fmars.2016.00072, 2016.

Levin, L. A., Mendoza, G. F., Konotchick, T., and Lee, R.: Macrobenthos community structure and trophic relationships within active and inactive Pacific hydrothermal sediments, Deep-Sea Res. Pt. II, 56, 1632-1648, 2009.

Levin, L. A., Ziebis, W., Mendoza, G. F., Bertics, V. J., Washington, T., Gonzalez, J., Thurber, A. R., Ebbed, B., and Lee, R. W.: Ecological release and niche partitioning under stress: Lessons from dorvilleid polychaetes in sulfidic sediments at methane seeps, Deep-Sea Res. Pt. II, 92, 214-233, 2013.

Liao, L., Wankel, S. D., Wu, M., Cavanaugh, C. M., and Girguis, P. R.: Characterizing the plasticity of nitrogen metabolism by the host and symbionts of the hydrothermal vent chemoautotrophic symbioses Ridgeia piscesae, Mol. Ecol., 23, 1544-1557, 2014.

Main, C. E., Ruhl, H. A., Jones, D. O. B., Yool, A., Thornton, B., and Mayor, D. J.: Hydrocarbon contamination affects deep-sea benthic oxygen uptake and microbial community composition, Deep-Sea Res. Pt. I, 100, 79-87, 2015. 
Martens, C. S.: Generation of short chain organic acid anions in hydrothermally altered sediments of the Guaymas Basin, Gulf of California, Appl. Geochem., 5, 71-76, 1990.

McCaffrey, M. A., Farrington, J. W., and Repeta, D. J.: Geochemical implications of the lipid composition of Thioploca spp. from the Peru upwelling region $-15^{\circ} \mathrm{S}$, Org. Geochem., 14, 6168, 1989.

McClain, C. R. and Schlacher, T. A.: On some hypotheses of diversity of animal life at great depths on the sea floor, Mar. Ecol., 36, 849-872, 2015.

Mehta, M. P. and Baross, J. A.: Nitrogen Fixation at $92^{\circ} \mathrm{C}$ by a Hydrothermal Vent Archaeon, Science, 314, 1783-1786, 2006.

Mincks, S. L., Smith, C. R., Jeffreys, R. M., and Sumida, P. Y. G.: Trophic structure on the West Antarctic Peninsula shelf: Detritivory and benthic inertia revealed by $\delta^{13} \mathrm{C}$ and $\delta 15^{\circ} \mathrm{N}$ analysis, Deep-Sea Res. Pt. II, 55, 2502-2514, 2008.

Naraoka, H., Naito, T., Yamanaka, T., Tsunogai, U., and Fujikura, K.: A multi-isotope study of deep-sea mussels at three different hydrothermal vent sites in the northwestern Pacific, Chem. Geol., 255, 25-32, 2008.

Ondov, B. D., Bergman, N. H., and Phillippy, A. M.: Interactive metagenomic visualization in a Web browser, BMC Bioinformatics, 12, 385, https://doi.org/10.1186/1471-2105-12-385, 2011.

Parnell, A. C., Inger, R., Bearhop, S., and Jackson, A. L.: Source partitioning using stable isotopes: coping with too much variation, PLoS One, 5, e9672, https://doi.org/10.1371/journal.pone.0009672, 2010.

Petersen, S., Herzig, P. M., Schwarz-Schampera, U., Hannington, M. D., and Jonasson, I. R.: Hydrothermal precipitates associated with bimodal volcanism in the Central Bransfield Strait, Antarctica, Miner. Deposita, 39, 358-379, 2004.

Phillips, D. L., Inger, R., Bearhop, S., Jackson, A. L., Moore, J. W., Parnell, A. C., Semmens, B. X., and Ward, E. J.: Best practices for use of stable isotope mixing models in food-web studies, Can. J. Zool., 92, 823-835, 2014.

Pina-Ochoa, E., Koho, K. A., Geslin, E., and Risgaard-Petersen, N.: Survival and life strategy of the foraminiferan Globobulimina turgida though nitrate storage and denitrification, Mar. Ecol. Prog. Ser., 417, 39-49, 2010.

Pond, D. W., Bell, M. V., Dixon, D. R., Fallick, A. E., Segonzac, M., and Sargent, J. R.: Stable-Carbon-Isotope Composition of Fatty Acids in Hydrothermal Vent Mussels Containing Methanotrophic and Thiotrophic Bacterial Endosymbionts, Appl. Environ. Microb., 64, 370-375, 1998.

Portail, M., Olu, K., Dubois, S. F., Escobar-Briones, E., Gelinas, Y., Menot, L., and Sarrazin, J.: Food-Web Complexity in Guaymas Basin Hydrothermal Vents and Cold Seeps, PLoS One, 11, e0162263, https://doi.org/10.1371/journal.pone.0162263, 2016.

R Core Team: A Language and environment for statistical computing, R Foundation for Statistical Computing, Vienna, Austria http://www.R-project.org/ (last access: 25 October 2017), 2013.

Rau, G. H.: Low ${ }^{15} \mathrm{~N} /{ }^{14} \mathrm{~N}$ in hydrothermal vent animals: ecological implications, Nature, 289, 484-485, 1981.

Reid, W. D. K., Sweeting, C. J., Wigham, B. D., Zwirglmaier, K., Hawkes, J. A., McGill, R. A. R., Linse, K., and Polunin, N. V. C.: Spatial Differences in East Scotia Ridge Hydrothermal Vent Food Webs: Influences of Chemistry, Microbiology and Predation on Trophodynamics, Plos One, 8, e65553, https://doi.org/10.1371/journal.pone.0065553, 2013.
Reid, W. D. K., Wigham, B. D., McGill, R. A. R., and Polunin, N. V. C.: Elucidating trophic pathways in benthic deep-sea assemblages of the Mid-Atlantic Ridge north and south of the CharlieGibbs Fracture Zone, Mar. Ecol. Prog. Ser., 463, 89-103, 2012.

Rennie, M. D., Ozersky, T., and Evans, D. O.: Effects of formalin preservation on invertebrate stable isotope values over decadal time scales, Can. J. Zool., 90, 1320-1327, 2012.

Rodrigues, C. F., Hilário, A., and Cunha, M. R.: Chemosymbiotic species from the Gulf of Cadiz (NE Atlantic): distribution, life styles and nutritional patterns, Biogeosciences, 10, 2569-2581, https://doi.org/10.5194/bg-10-2569-2013, 2013.

Sahling, H., Wallman, K., Dählmann, A., Schmaljohann, R., and Petersen, S.: The physicochemical habitat of Sclerolinum sp. at Hook Ridge hydrothermal vent, Bransfield Strait, Antarctica, Limnol. Oceanogr., 50, 598-606, 2005.

Schlesner, H.: Blastopirellula, Bergey's Manual of Systematics of Archaea and Bacteria, John Wiley and Sons Ltd., 1-13, 2015.

Schmaljohann, R., Faber, E., Whiticar, M. J., and Dando, P. R.: Co-existence of methane- and sulphur-based endosymbioses between bacteria and invertebrates at a site in the Skagerrak, Mar. Ecol. Prog. Ser., 61, 11-124, 1990.

Schmaljohann, R. and Flügel, H. J.: Methane-oxidizing bacteria in Pogonophora, Sarsia, 72, 91-98, 1987.

Sellanes, J., Zapata-Hernández, G., Pantoja, S., and Jessen, G. L.: Chemosynthetic trophic support for the benthic community at an intertidal cold seep site at Mocha Island off central Chile, Estuarine, Coast. Shelf Sci., 95, 431-439, 2011.

Soto, L. A.: Stable carbon and nitrogen isotopic signatures of fauna associated with the deep-sea hydrothermal vent system of Guaymas Basin, Gulf of California, Deep-Sea Res. Pt. II, 56, 16751682, 2009.

Southward, A. J., Southward, E. C., Brattegard, T., and Bakke, T.: Further Experiments on the value of Dissolved Organic Matter as Food for Siboglinum fjiordicum (Pogonophora), J. Mar. Biol. Asoc. UK, 59, 133-148, 1979.

Sweetman, A. K., Levin, L. A., Rapp, H. T., and Schander, C.: Faunal trophic structure at hydrothermal vents on the southern Mohn's Ridge, Arctic Ocean, Mar. Ecol. Prog. Ser., 473, 115131, 2013.

Tarasov, V. G., Gebruk, A. V., Mironov, A. N., and Moskalev, L. I.: Deep-sea and shallow-water hydrothermal vent communities: Two different phenomena?, Chem. Geol., 224, 5-39, 2005.

Teske, A., Callaghan, A. V., and LaRowe, D. E.: Biosphere frontiers of subsurface life in the sedimented hydrothermal system of Guaymas Basin, Front. Microbiol., 5, 362, https://doi.org/10.3389/fmicb.2014.00362, 2014.

Teske, A., Hinrichs, K. U., Edgcomb, V., de Vera Gomez, A., Kysela, D., Sylva, S. P., Sogin, M. L., and Jannasch, H. W.: Microbial Diversity of Hydrothermal Sediments in the Guaymas Basin: Evidence for Anaerobic Methanotrophic Communities, Appl. Environ. Microbiol., 68, 1994-2007, 2002.

Thornhill, D. J., Wiley, A. A., Campbell, A. L., Bartol, F. F., Teske, A., and Halanych, K. M.: Endosymbionts of Siboglinum fjordicum and the Phylogeny of Bacterial Endosymbionts in Siboglinidae (Annelida), Biol. Bull., 214, 135-144, 2008.

Thornton, B., Zhang, Z., Mayes, R. W., Högberg, M. N., and Midwood, A. J.: Can gas chromatography combustion isotope ratio mass spectrometry be used to quantify organic compound abundance?, Rapid Commun. Mass Sp., 25, 2433-2438, 2011. 
Tyler, P. A., Connelly, D. P., Copley, J. T., Linse, K., Mills, R. A., Pearce, D. A., Aquilina, A., Cole, C., Glover, A. G., Green, D. R., Hawkes, J. A., Hepburn, L., Herrera, S., Marsh, L., Reid, W. D., Roterman, C. N., Sweeting, C. J., Tate, A., Woulds, C., and Zwirglmaier, K.: RRS James Cook cruise JC55: Chemosynthetic Ecosystems of the Southern Ocean, BODC Cruise Report, 2011.

Valls, M., Olivar, M. P., Fernández de Puelles, M. L., Molí, B., Bernal, A., and Sweeting, C. J.: Trophic structure of mesopelagic fishes in the western Mediterranean based on stable isotopes of carbon and nitrogen, J. Mar. Syst., 138, 160-170, 2014.

Vetter, R. D. and Fry, B.: Sulfur contents and sulfur-isotope compositions of thiotrophic symbioses in bivalve molluscs and vestimentiferan worms, Mar. Biol., 132, 453-460, 1998.

Veuger, B., van Oevelen, D., and Middelburg, J. J.: Fate of microbial nitrogen, carbon, hydrolysable amino acids, monosaccharides, and fatty acids in sediment, Geochim. Cosmochim. Ac., 83, 217-233, 2012.

Walker, B. D., McCarthy, M. D., Fisher, A. T., and Guilderson, T. P.: Dissolved inorganic carbon isotopic composition of lowtemperature axial and ridge-flank hydrothermal fluids of the Juan de Fuca Ridge, Mar. Chem., 108, 123-136, 2008.

Wang, Q., Garrity, G. M., Tiedje, J. M., and Cole, J. R.: Naïve Bayesian Classifier for Rapid Asssignment of rRNA sequences into the New Bacterial Taxonomy, Appl. Environ. Microbiol., 73, 5261-5267, 2007.

Whitaker, D. and Christmann, M.: Package "clustsig", cranrprojectorg, https://cran.r-project.org/web/packages/clustsig/ index.html, last access: 1 September 2013.

Whiticar, M. J.: Carbon and Hydrogen isotope systematics of bacterial formation and oxidation of methane, Chem. Geol., 161, 291314, 1999.

Whiticar, M. J. and Suess, E.: Hydrothermal hydrocarbon gases in the sediments of the King George Basin, Bransfield Strait, Antarctica, Appl. Geochem., 5, 135-147, 1990.
Woolley, S. N. C., Tittensor, D. P., Dunstan, P. K., Guillera-Arroita, G., Lahoz-Monfort, J. J., Wintle, B. A., Worm, B., and O'Hara, T. D.: Deep-sea diversity patterns are shaped by energy availability, Nature, 533, 393-396, 2016.

Wu, Y., Cao, Y., Wang, C., Wu, M., Aharon, O., and Xu, X.: Microbial community structure and nitrogenase gene diversity of sediment from a deep-sea hydrothermal vent field on the Southwest Indian Ridge, Acta Oceanol. Sin., 33, 94-104, 2014.

Würzberg, L., Peters, J., Schüller, M., and Brandt, A.: Diet insights of deep-sea polychaetes derived from fatty acids analyses, DeepSea Res. Pt. II, 58, 153-162, 2011.

Yamanaka, T. and Sakata, S.: Abundance and distribution of fatty acids in hydrothermal vent sediments of the western Pacific Ocean, Org. Geochem., 35, 573-582, 2004.

Yamanaka, T., Shimamura, S., Nagashio, H., Yamagami, S., Onishi, Y., Hyodo, A., Mampuku, M., and Mizota, C.: A Compilation of the Stable Isotopic Compositions of Carbon, Nitrogen, and Sulfur in Soft Body Parts of Animals Collected from Deep-Sea Hydrothermal Vent and Methane Seep Fields: Variations in Energy Source and Importance of Subsurface Microbial Processes in the Sediment-Hosted Systems, in: Subseafloor Biosphere Linked to Hydrothermal Systems, edited by: Ishibashi, J., Okino, K., and Sunamura, M., SpringerOpen, Tokyo, 2015.

Yorisue, T., Inoue, K., Miyake, H., and Kojima, S.: Trophic structure of hydrothermal vent communities at Myojin Knoll and Nikko Seamount in the northwestern Pacific: Implications for photosynthesis-derived food supply, Plankton and Benthos Research, 7, 35-40, 2012.

Young, J. N., Bruggeman, J., Rickaby, R. E. M., Erez, J., and Conte, M.: Evidence for changes in carbon isotopic fractionation by phytoplankton between 1960 and 2010, Global Biogeochem. Cy., 27, 505-515, 2013. 